Supporting Information

\title{
Precipitated Fluorophore-based Probe for Accurate Detection of Mitochondrial Analytes
}

Zhe Li, Tian-Bing Ren, Xing-Xing Zhang, Shuai Xu, Xiang-Yang Gong, Yue Yang, Guoliang Ke,* Lin Yuan, Xiao-Bing Zhang*

$\dagger$ Molecular Science and Biomedicine Laboratory (MBL), State Key Laboratory of Chemo/Biosensing and Chemometrics, College of Chemistry and Chemical Engineering, College of Life Sciences, Hunan University, Changsha 410082, China

E-mail: xbzhang@hnu.edu.cn, glke@hnu.edu.cn 


\section{Table of contents:}

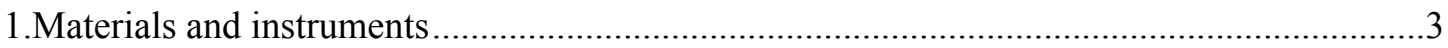

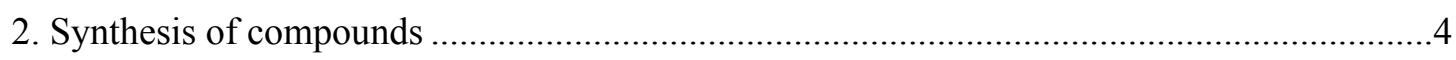

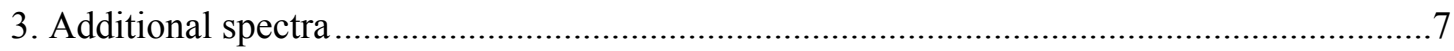

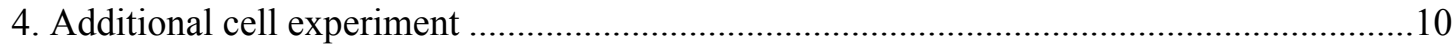

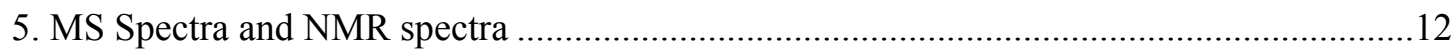

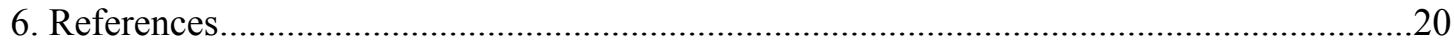




\section{Materials and instruments}

Materials and instruments. Unless otherwise stated, all reagents were purchased from commercial suppliers and used without further purification. Lyso-Blue were purchased from Xiamen Bioluminor Bio-Technology Co., Ltd. Mito-Red were purchased from Beyotime and PMA was purchased from Accelerating Scientific and Industrial Development thereby Serving Humanity. Mito-Green were purchased from Beyotime. Solvents were purified by standard methods prior to use. Twice-distilled water was used throughout all experiments. Mass spectra were performed using an Agilent 1200-6520 Q-TOF mass spectrometer system operating in a MALDI-TOF mode. NMR spectra were recorded on Bruker-400, using TMS as the internal standard. UV-Vis spectra were recorded on a UV-1800 spectrophotometer (Shimadzu Corporation, Japan). One-photon photoluminescence spectra were recorded on a HITACHI F4600 fluorescence spectrophotometer with a $1 \mathrm{~cm}$ standard quartz cell. Cell imaging was performed on Nikon Alplus confocal microscope. The $\mathrm{pH}$ measurements were carried out on a PHS-3C pH meter (INESA instrument). Transmission electron microscope (TEM) images were performed by JEM-2100F (JEOL). TLC analysis was performed on silica gel plates and column chromatography was conducted over silica gel (mesh 200-300) columns, obtained from the Yantai Jiangyou silica gel Development Company Limited.

Detection limit calculation. The detection limit was calculated based on the fluorescence titration. The detection limit is calculated using the following equation: $3 \sigma / \mathrm{k}$

where $\sigma$ is the standard deviation of blank measurements, $\mathrm{k}$ is the slope between the emission ratios versus sample concentration. 


\section{Synthesis of compounds}

(A)
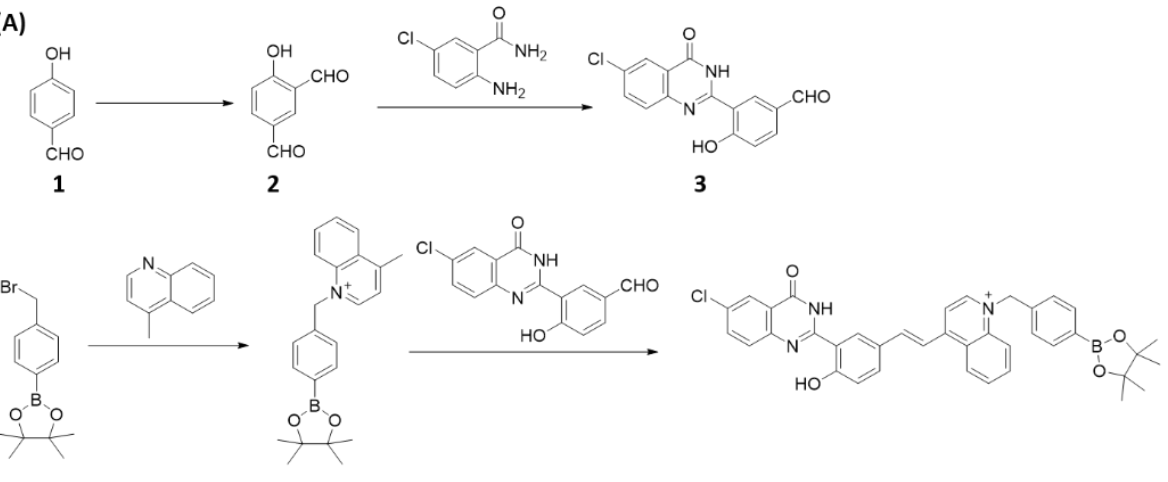

HQPQ-B
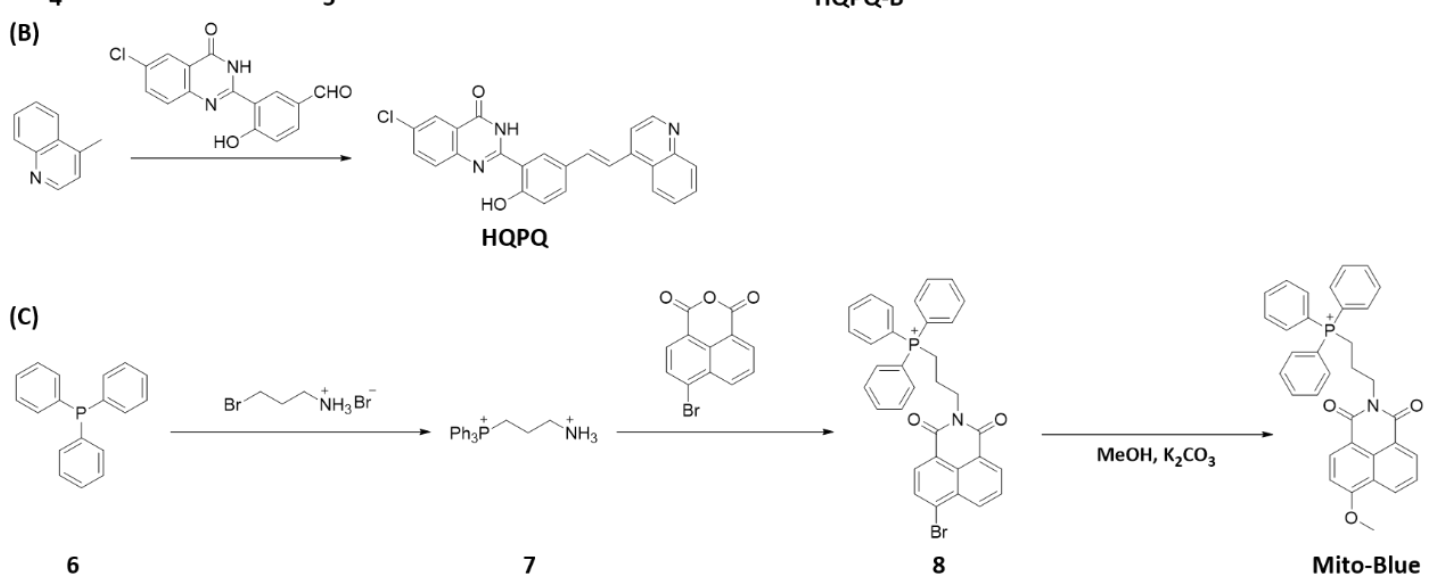

(D)

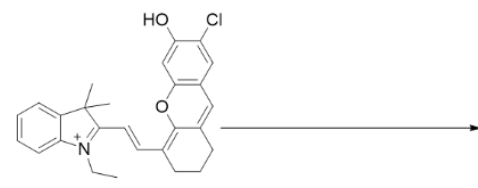

HD

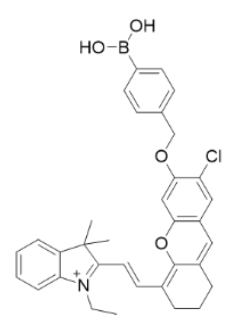

HD-B

Scheme S1. Synthetic route of HQPQ-B (A), HQPQ (B), Mito-Blue (C), and HD-B (D).

Synthesis of compound 2. Compound $1(5 \mathrm{~g}, 41 \mathrm{mmol})$ and urotropine $(5.7 \mathrm{~g}, 41 \mathrm{mmol})$ were placed in a round bottom flask and $20 \mathrm{~mL}$ trifluoroacetic acid was added and stirred at $90^{\circ} \mathrm{C}$ for $6 \mathrm{~h}$ under nitrogen. After cooling, $20 \mathrm{~mL}$ of $4 \mathrm{M} \mathrm{HCl}$ was added and stirred at $95^{\circ}$ $\mathrm{C}$ overnight. After that, it was extracted with ethyl acetate and washed with a saturated $\mathrm{NaHCO} 3$ aqueous solution. The organic phase was taken and dried by rotary evaporator and purified by column chromatography (silica gel, $\mathrm{DCM} / \mathrm{PE}=1: 1$ ) to give a white solid $2.9 \mathrm{~g}$ (Yield 47.11\%). ${ }^{1} \mathrm{H}$ NMR (400 MHz, Chloroform-d) $\delta 11.59$ (s, 1H), 10.04 (d, J = 2.6 Hz, $1 \mathrm{H}), 9.97$ (d, J = 2.7 Hz, 1H), 8.19 (s, 1H), $8.14-8.05$ (m, 1H), 7.16 (dd, J = 8.6, $2.4 \mathrm{~Hz}$, $1 \mathrm{H})$. 
Synthesis of compound 3. According to previous literature ${ }^{1} .{ }^{1} \mathrm{H}$ NMR (400 MHz, DMSO- $\mathrm{d}_{6}$ ) $\delta 12.78(\mathrm{~s}, 1 \mathrm{H}), 11.46(\mathrm{~s}, 1 \mathrm{H}), 10.37(\mathrm{~s}, 1 \mathrm{H}), 8.60-8.53(\mathrm{~m}, 1 \mathrm{H}), 8.35(\mathrm{dd}, \mathrm{J}=8.7,2.4 \mathrm{~Hz}$, $1 \mathrm{H}), 8.09(\mathrm{~d}, \mathrm{~J}=2.4 \mathrm{~Hz}, 1 \mathrm{H}), 7.88(\mathrm{dd}, \mathrm{J}=8.8,2.5 \mathrm{~Hz}, 1 \mathrm{H}), 7.78(\mathrm{~d}, \mathrm{~J}=8.7 \mathrm{~Hz}, 1 \mathrm{H}), 7.17(\mathrm{~d}$, $\mathrm{J}=8.8 \mathrm{~Hz}, 1 \mathrm{H}$ ). MS (MALDI-TOF): calcd for $\mathrm{C}_{15} \mathrm{H}_{9} \mathrm{ClN}_{2} \mathrm{O}_{3}(\mathrm{M}+\mathrm{H})^{+} 301.0$, found 301.0.

Synthesis of compound 5. According to previous literature ${ }^{2} .{ }^{1} \mathrm{H}$ NMR (400 MHz, DMSO- $\mathrm{d}_{6}$ ) $\delta 9.82-9.71(\mathrm{~m}, 1 \mathrm{H}), 8.64-8.54(\mathrm{~m}, 1 \mathrm{H}), 8.44(\mathrm{~d}, \mathrm{~J}=8.9 \mathrm{~Hz}, 1 \mathrm{H}), 8.25(\mathrm{~d}, \mathrm{~J}=6.0 \mathrm{~Hz}, 1 \mathrm{H})$, $8.18(\mathrm{t}, \mathrm{J}=7.9 \mathrm{~Hz}, 1 \mathrm{H}), 8.03(\mathrm{t}, \mathrm{J}=7.7 \mathrm{~Hz}, 1 \mathrm{H}), 7.68(\mathrm{~d}, \mathrm{~J}=7.9 \mathrm{~Hz}, 2 \mathrm{H}), 7.44-7.35(\mathrm{~m}, 2 \mathrm{H})$, $6.45(\mathrm{~s}, 2 \mathrm{H}), 3.08(\mathrm{~s}, 3 \mathrm{H}), 1.27(\mathrm{~s}, 12 \mathrm{H})$.

Synthesis of compound HQPQ. 4-methylquinoline ( $40 \mathrm{mg}, 0.28 \mathrm{mmol}$ ) and compound 3 (60 $\mathrm{mg}, 0.2 \mathrm{mmol}$ ) were placed in a round bottom flask, $2 \mathrm{~mL}$ DMF was added and p-toluenesulfonic acid $(0.06 \mathrm{~g}, 0.34 \mathrm{mmol})$ was added, then refluxed at $135^{\circ} \mathrm{C}$ for $6 \mathrm{~h}$ under nitrogen. After cooling, $10 \mathrm{~mL}$ of water was added and the reaction mixture was filtered to give a solid. Rinse with a small amount of ethanol to give a yellow solid $19 \mathrm{mg}$ (Yield $23.53 \%$ \%). ${ }^{1} \mathrm{H}$ NMR (400 MHz, DMSO-d $\left.{ }_{6}\right) \delta 12.61(\mathrm{~s}, 1 \mathrm{H}), 10.88(\mathrm{~s}, 0 \mathrm{H}), 9.87(\mathrm{~s}, 1 \mathrm{H}), 8.93(\mathrm{t}$, $\mathrm{J}=4.4 \mathrm{~Hz}, 1 \mathrm{H}), 8.81(\mathrm{~s}, 1 \mathrm{H}), 8.69(\mathrm{~s}, 1 \mathrm{H}), 8.12(\mathrm{~d}, \mathrm{~J}=16.4 \mathrm{~Hz}, 4 \mathrm{H}), 7.87(\mathrm{~d}, \mathrm{~J}=11.1 \mathrm{~Hz}$, 5H), $7.11(\mathrm{~d}, \mathrm{~J}=14.4 \mathrm{~Hz}, 1 \mathrm{H}) .{ }^{13} \mathrm{C}$ NMR $\left(101 \mathrm{MHz}, \mathrm{DMSO}-\mathrm{d}_{6}\right) \delta 198.2,190.8,161.0,154.0$, $150.5,148.5,146.4,145.5,135.5,134.7,134.1,133.7,132.9,131.6,130.0,130.0,128.8$, 128.1, 127.0, 125.5, 121.0, 119.5, 116.9, 115.2. MS (MALDI-TOF): calcd for $\mathrm{C}_{25} \mathrm{H}_{16} \mathrm{ClN}_{3} \mathrm{O}_{2}$ $(\mathrm{M}+\mathrm{H})^{+} 426.0$, found 426.0 .

Synthesis of compound 7. According to previous literature ${ }^{3} .{ }^{1} \mathrm{H}$ NMR (400 $\mathrm{MHz}$, Methanol-d4) $\delta 7.94(\mathrm{dd}, \mathrm{J}=12.8,7.6 \mathrm{~Hz}, 9 \mathrm{H}), 7.84(\mathrm{td}, \mathrm{J}=7.7,3.5 \mathrm{~Hz}, 6 \mathrm{H}), 3.82-3.72(\mathrm{~m}$, $2 \mathrm{H}), 3.32(\mathrm{t}, \mathrm{J}=7.5 \mathrm{~Hz}, 2 \mathrm{H}), 2.18-2.06(\mathrm{~m}, 2 \mathrm{H})$.

Synthesis of compound 8. According to previous literature ${ }^{3} .{ }^{1} \mathrm{H}$ NMR $(400 \mathrm{MHz}$, Chloroform-d) $\delta 8.49(\mathrm{~d}, \mathrm{~J}=8.2 \mathrm{~Hz}, 2 \mathrm{H}), 8.24(\mathrm{dd}, \mathrm{J}=7.8,1.5 \mathrm{~Hz}, 1 \mathrm{H}), 7.96$ (dd, J = 7.8, 1.4 $\mathrm{Hz}, 1 \mathrm{H}), 7.86(\mathrm{dd}, \mathrm{J}=12.7,7.9 \mathrm{~Hz}, 6 \mathrm{H}), 7.80-7.74(\mathrm{~m}, 4 \mathrm{H}), 7.72-7.67(\mathrm{~m}, 6 \mathrm{H}), 4.43(\mathrm{t}, \mathrm{J}=$ $7.0 \mathrm{~Hz}, 2 \mathrm{H}), 4.06(\mathrm{dt}, \mathrm{J}=14.4,7.9 \mathrm{~Hz}, 2 \mathrm{H}), 2.16(\mathrm{dq}, \mathrm{J}=16.0,8.6 \mathrm{~Hz}, 2 \mathrm{H})$.

Synthesis of compound Mito-Blue. Compound $8(20 \mathrm{mg}, 0.0346 \mathrm{mmol})$ and $\mathrm{K}_{2} \mathrm{CO}_{3}(4.78$ $\mathrm{mg}, 0.0346 \mathrm{mmol}$ ) were placed in a round bottom flask, and $3 \mathrm{~mL} \mathrm{MeOH}$ was added and refluxed for $5 \mathrm{~h}$. After cooling, the reaction solution was dried by rotary evaporator and purified by column chromatography (silica gel, $\mathrm{DCM} / \mathrm{EtOH}=30: 1$ ) to give a pink solid $4 \mathrm{mg}$ (Yield $21.79 \%$ \%). ${ }^{1} \mathrm{H}$ NMR (400 MHz, Chloroform-d) $\delta 8.57$ (dd, J = 16.6, 7.6 Hz, 4H), $7.81-$ $7.71(\mathrm{~m}, 6 \mathrm{H}), 7.49(\mathrm{dd}, \mathrm{J}=15.5,6.1 \mathrm{~Hz}, 9 \mathrm{H}), 7.06(\mathrm{~d}, \mathrm{~J}=8.3 \mathrm{~Hz}, 1 \mathrm{H}), 4.30(\mathrm{t}, \mathrm{J}=6.8 \mathrm{~Hz}$, 2H), $4.16(\mathrm{~s}, 3 \mathrm{H}), 2.48-2.42(\mathrm{~m}, 2 \mathrm{H}), 2.14-2.08(\mathrm{~m}, 2 \mathrm{H}) .{ }^{13} \mathrm{C}$ NMR (101 MHz, Chloroform-d) $\delta 163.8,160.8,133.6,133.2,132.2,131.7,130.8,129.3,128.5,125.9,123.4$, 122.2, 114.8, 105.2, 56.2, 40.4, 27.9, 20.6. MS (MALDI-TOF): calcd for $\mathrm{C}_{34} \mathrm{H}_{29} \mathrm{NO}_{3} \mathrm{P}^{+}$ $\mathrm{M}^{+} 530.1$, found 529.9.

Synthesis of compound HD. According to previous literature ${ }^{4}$. MS (MALDI-TOF): calcd for $\mathrm{C}_{27} \mathrm{H}_{27} \mathrm{ClNO}_{2}{ }^{+} \mathrm{M}^{+} 432.1$, found 432.0 . 
Synthesis of compound HD-B. According to previous literature ${ }^{4}$. MS (MALDI-TOF): calcd for $\mathrm{C}_{34} \mathrm{H}_{34} \mathrm{BClNO}_{4}^{+} \mathrm{M}^{+} 566.2$, found 566.1.

\section{Additional spectra}
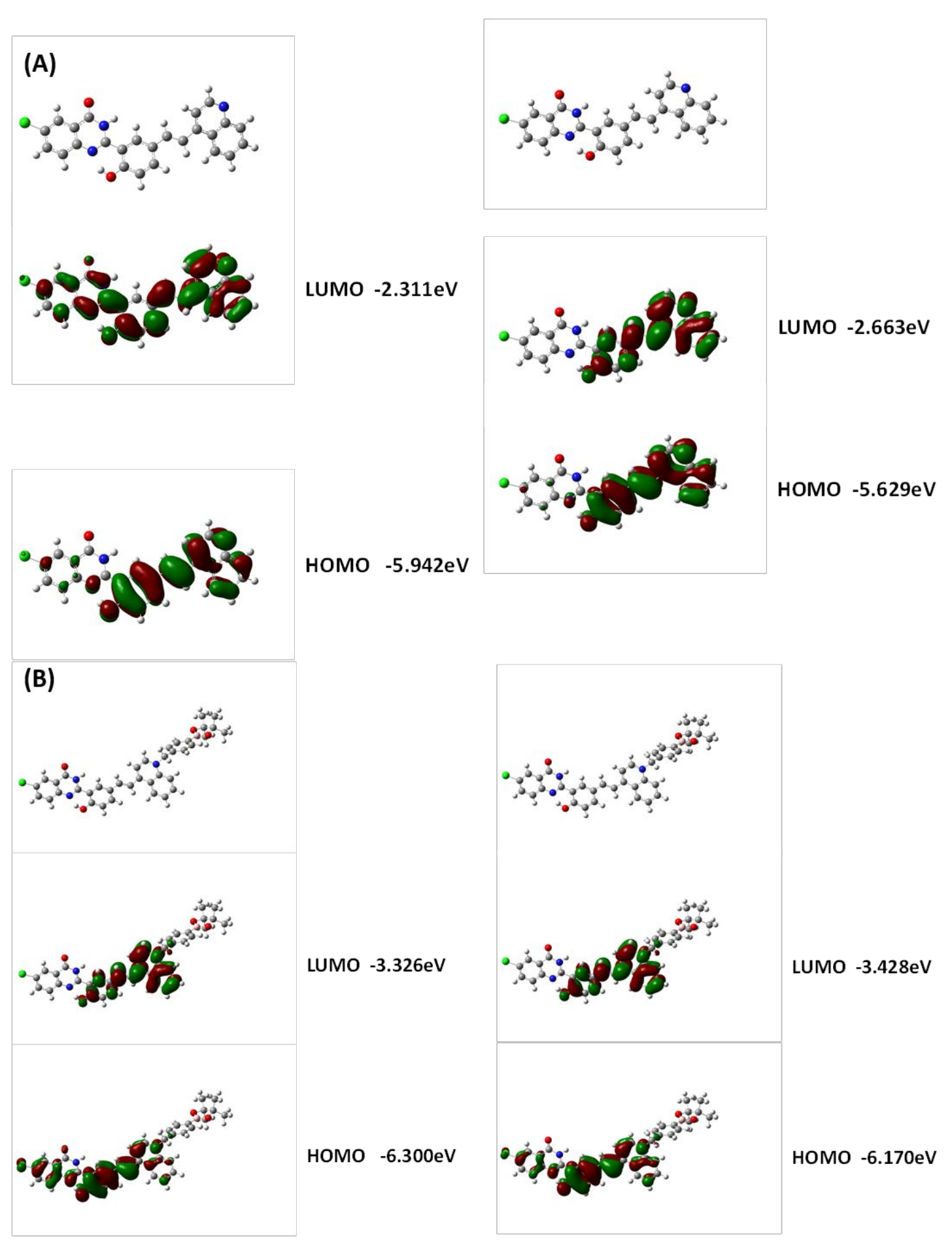

(B)

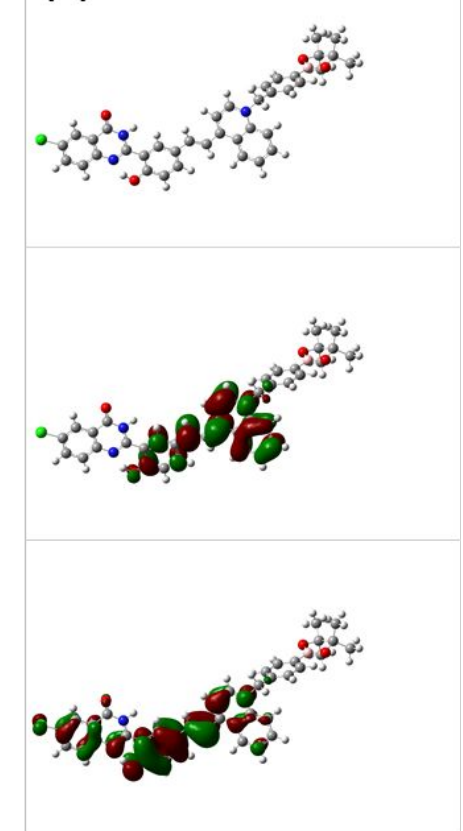


Figure. S1 (A) Structures and Energies of the HOMO and LUMO of HQPQ ground state and TD-SCF at the B3LYP/6-31+G $(+, \mathrm{d}), \Delta \mathrm{E}_{\text {gap }}=2.742 \mathrm{eV}$. (B) Structures and Energies of the HOMO and LUMO of HQPQ-B ground state and TD-SCF at the B3LYP/6-31+G $(+, d), \Delta \mathrm{E}_{\text {gap }}=2.966 \mathrm{eV}$.
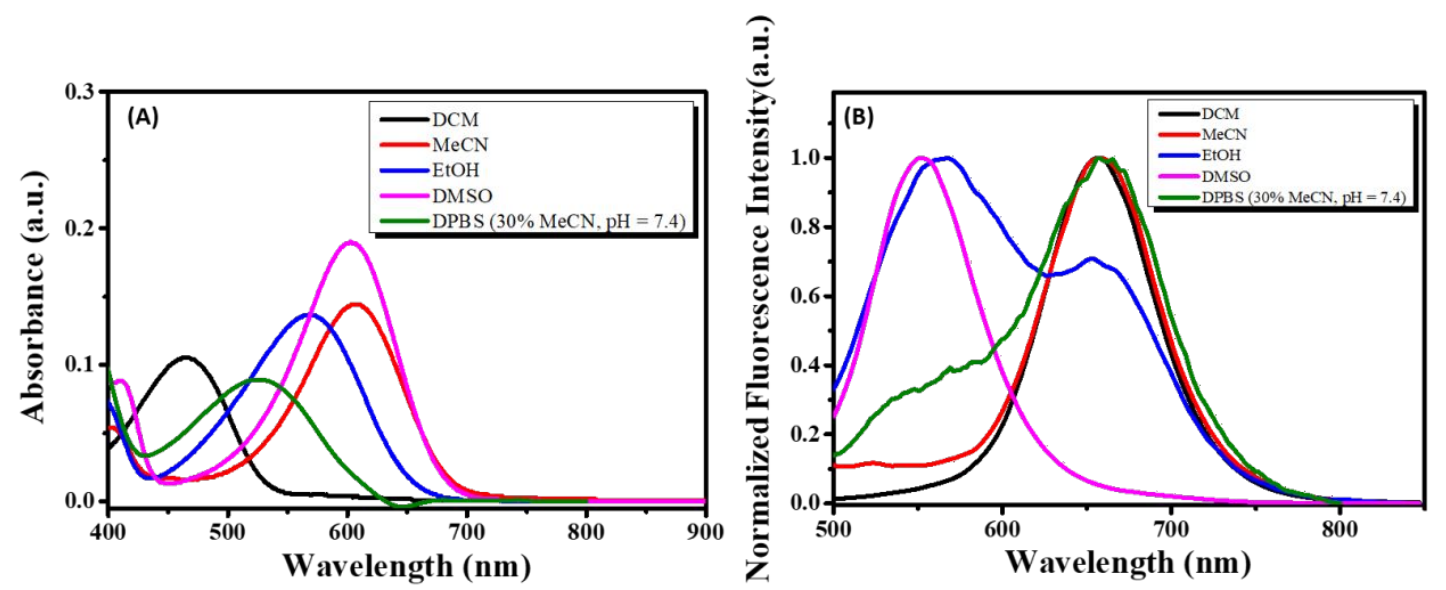

Figure. S2 (A) Absorbance spectra and (B) fluorescence spectra $\left(\lambda_{\mathrm{ex}}=450 \mathrm{~nm}\right)$ of HQPQ-B in different solvents.
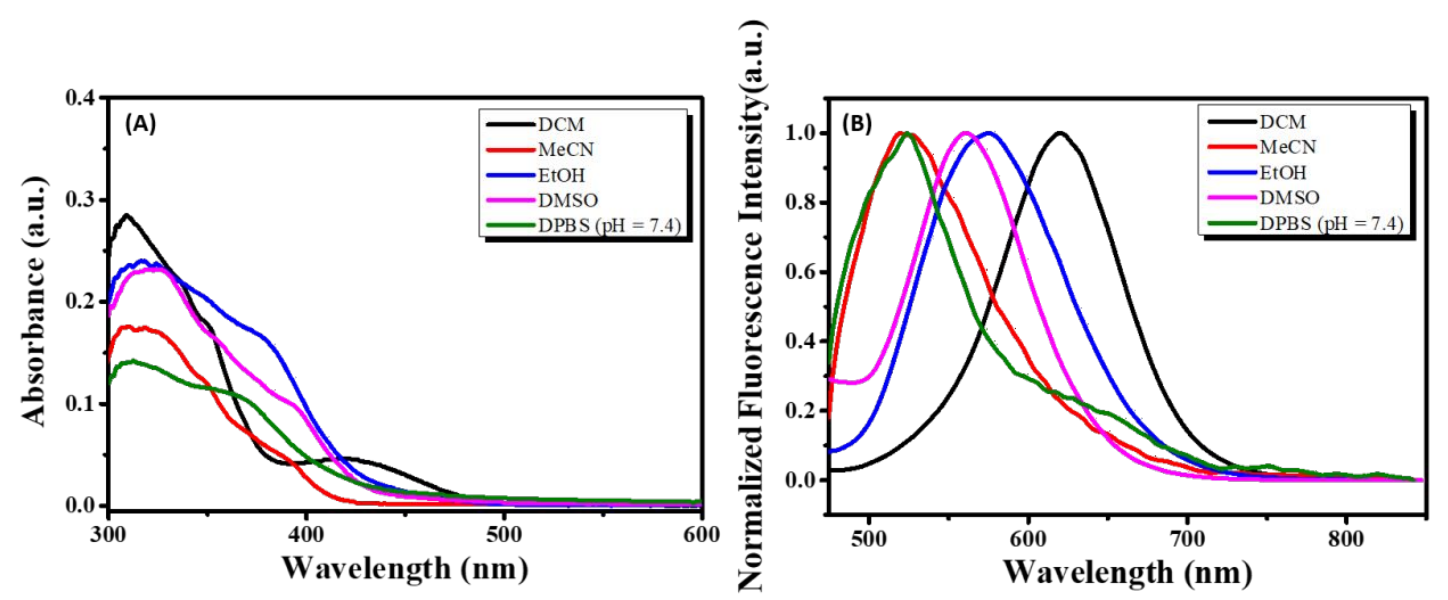

Figure. S3 (A) Absorbance spectra and (B) fluorescence spectra $\left(\lambda_{\mathrm{ex}}=450 \mathrm{~nm}\right)$ of HQPQ in different solvents.

Table. S1 Fluorescence quantum yield of HQPQ-B and HQPQ.

\begin{tabular}{|c|c|c|c|c|c|}
\hline$Q_{Y}$ & DCM & MeCN & DtOH & DMSO & DPBS $(\mathrm{pH}=7.4)$ \\
\hline HQPQ-B & 0.15 & 0.056 & 0.021 & 0.038 & $0.011^{\mathrm{a}}$ \\
\hline HQPQ & 0.19 & 0.050 & 0.054 & 0.15 & 0.056 \\
\hline
\end{tabular}

HQPQ-B (Reference fluorophore: Cresyl violet) and HQPQ (Reference fluorophore: Rhodamine B) in different solvents, ${ }^{\text {a }}$ Containing $30 \% \mathrm{MeCN}$. 

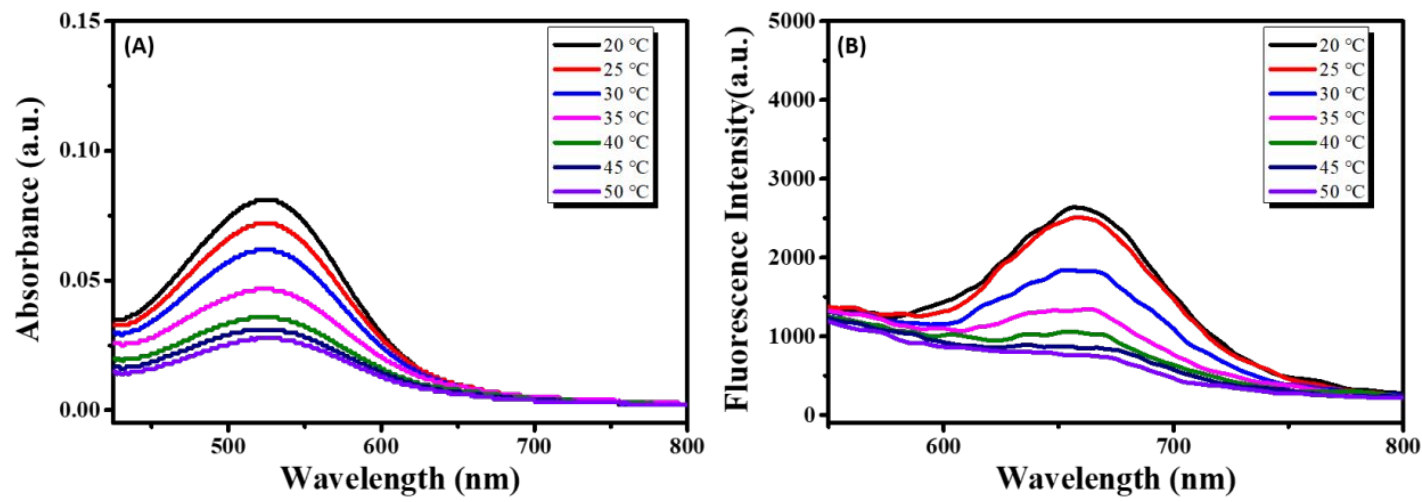

Figure. S4 (A) Absorbance spectra and (B) fluorescence spectra $\left(\lambda_{\mathrm{ex}}=450 \mathrm{~nm}\right)$ of HQPQ-B at different temperature. Buffer: $10 \mathrm{mM}$ DPBS $\mathrm{pH}=7.4, \mathrm{MeCN}$ : DPBS=3: 7.
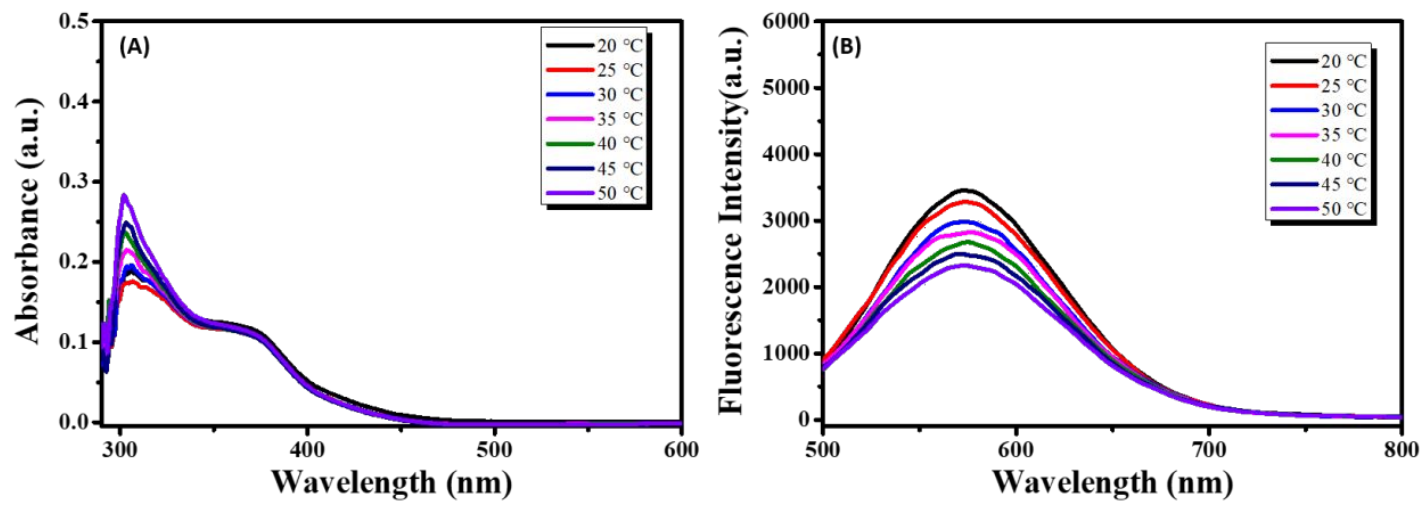

Figure. S5 (A) Absorbance spectra and (B) fluorescence spectra $\left(\lambda_{\mathrm{ex}}=450 \mathrm{~nm}\right)$ of HQPQ at different temperature. Buffer: $10 \mathrm{mM}$ DPBS pH=7.4, MeCN: DPBS= 3: 7 .
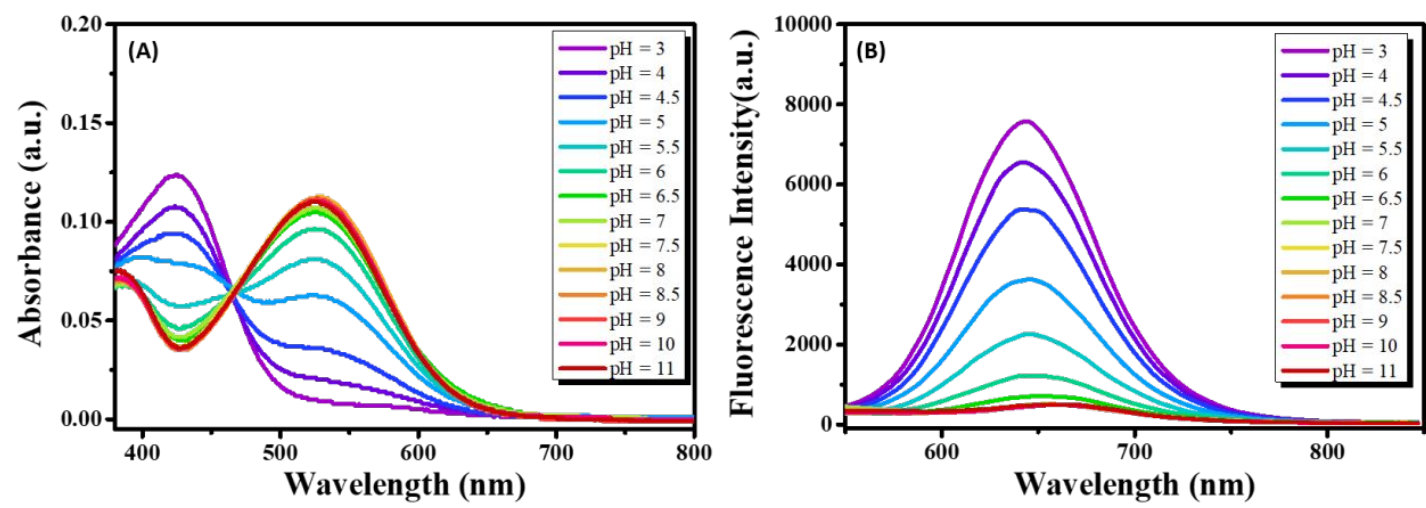

Figure. S6 (A) Absorbance spectra and (B) fluorescence spectra $\left(\lambda_{\mathrm{ex}}=450 \mathrm{~nm}\right)$ of HQPQ-B at different $\mathrm{pH}$. Buffer: $10 \mathrm{mM}$ DPBS, MeCN: DPBS=3: 7. The $p K a$ is calculated as 4.88 . 

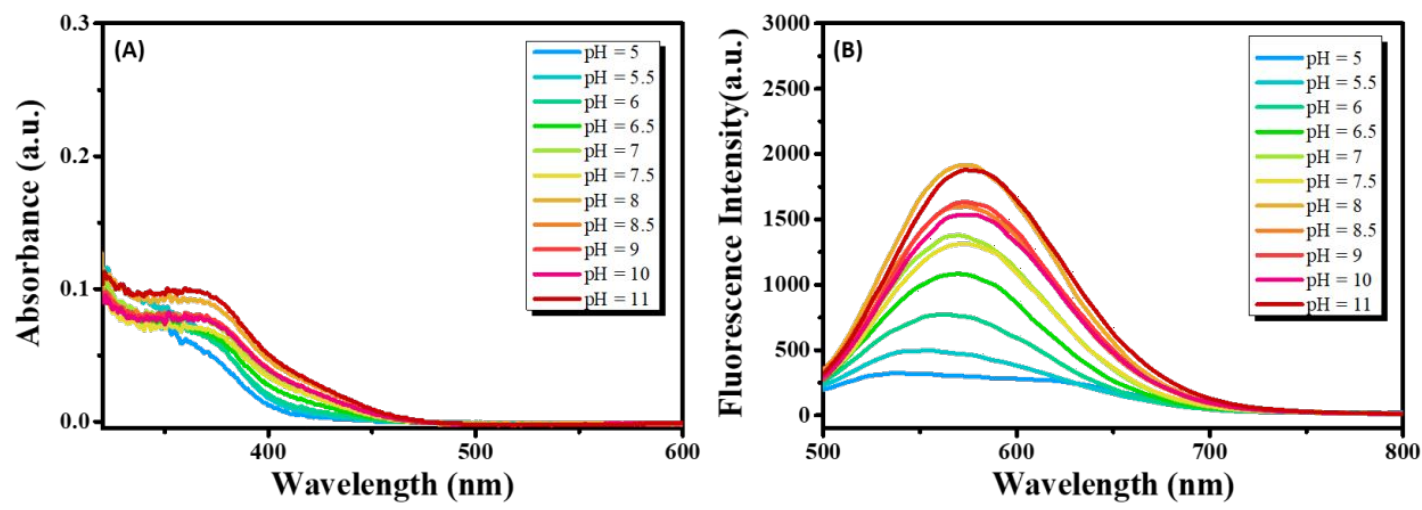

Figure. S7 (A) Absorbance spectra and (B) fluorescence spectra $\left(\lambda_{\mathrm{ex}}=450 \mathrm{~nm}\right)$ of HQPQ at different $\mathrm{pH}$. Buffer: $10 \mathrm{mM}$ DPBS, MeCN: DPBS $=3: 7$. The $p K a$ is calculated as 6.57 .
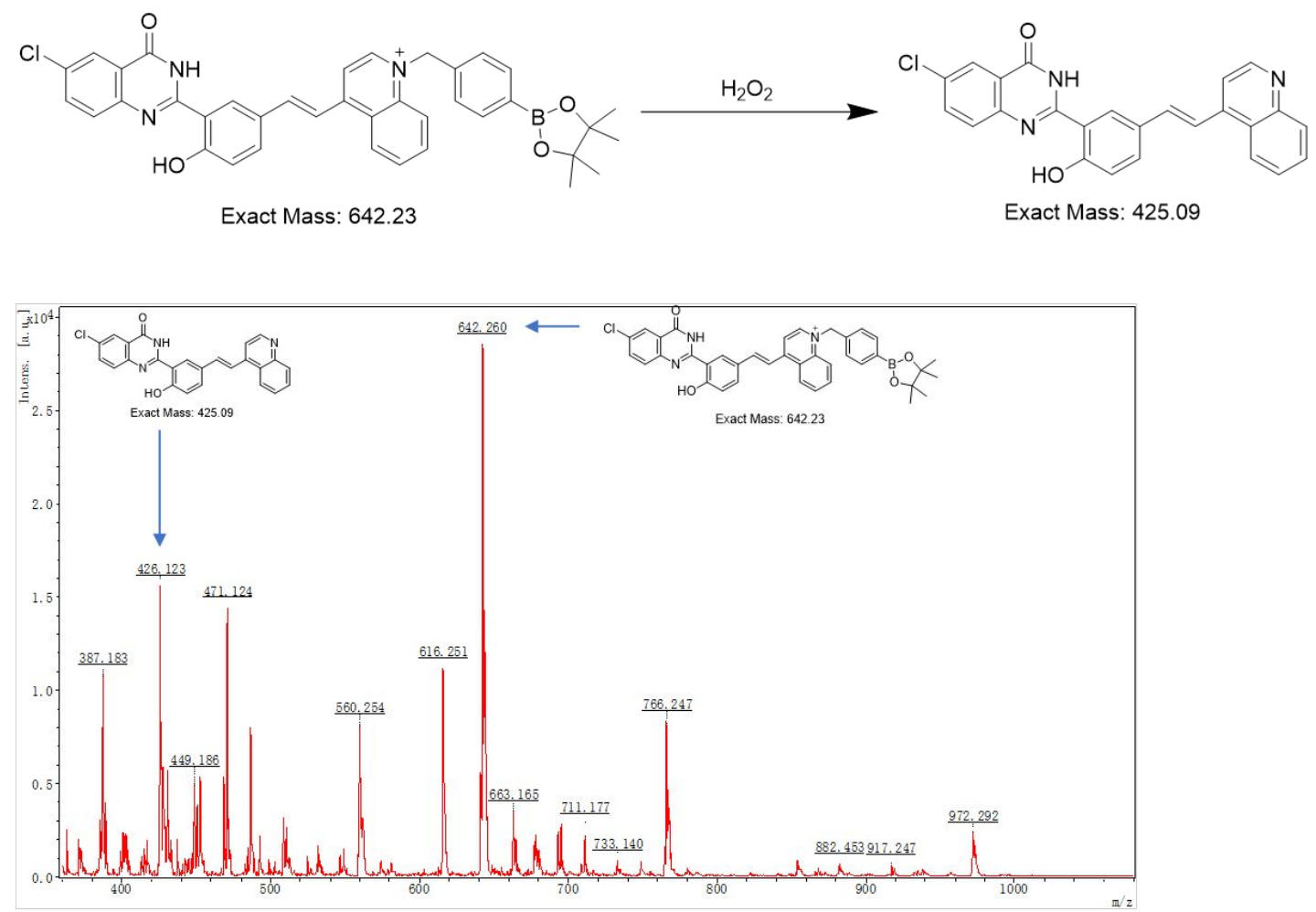

Figure. S8 MALDI-TOF mass spectrum of compound HQPQ-B in the presence of $\mathrm{H}_{2} \mathrm{O}_{2}$. 


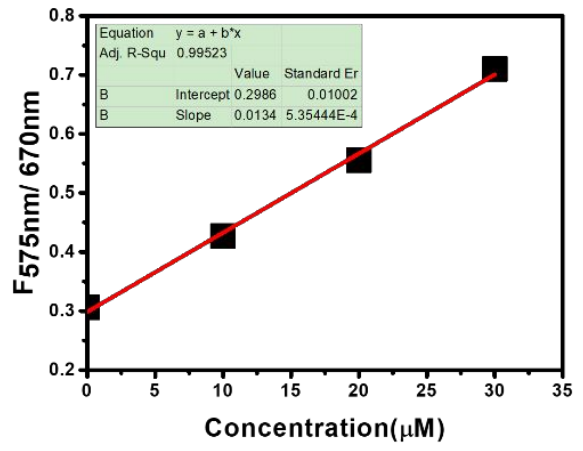

Figure. S9 The fluorescence intensity ratio $F_{575} / F_{670}$ has a good linearity in the concentration range of $0-30 \mu \mathrm{M}$.

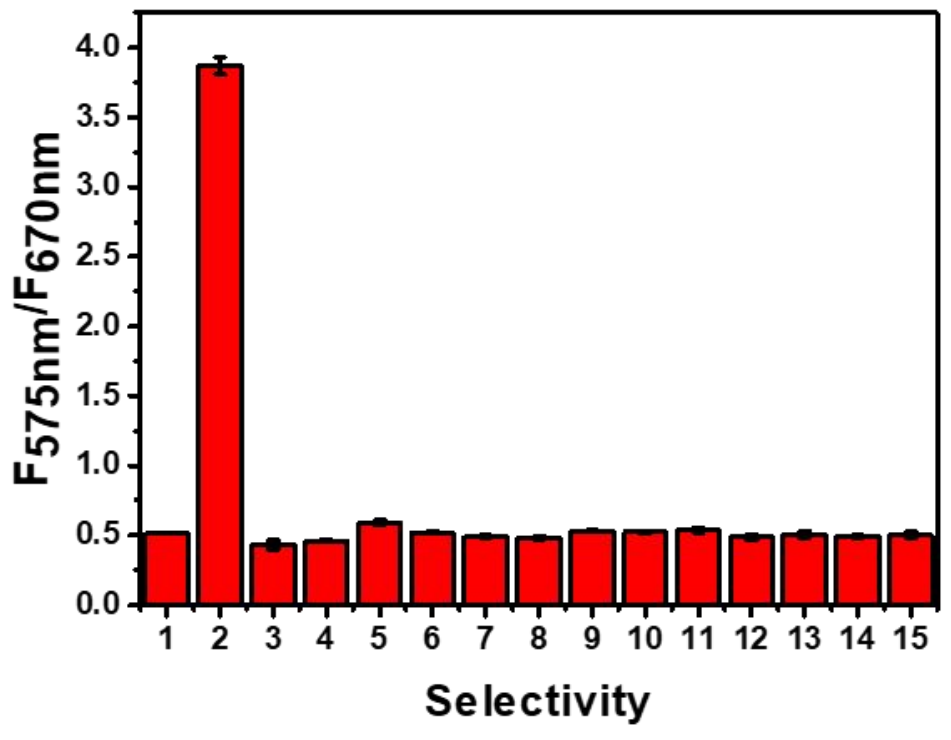

Figure. S10 Relative ratios of fluorescence intensity $\left(\mathrm{F}_{575 \mathrm{~nm}} / \mathrm{F}_{670 \mathrm{~nm}}\right)$ of HQPQ-B (10 $\mu \mathrm{M})$ to various analytes (1.blank, 2.100 $\mu \mathrm{M} \mathrm{H}_{2} \mathrm{O}_{2}$, 3. $20 \mu \mathrm{M}_{\mathrm{ONOO}}^{-}$, 4. $20 \mu \mathrm{M} \mathrm{OCl}^{-}$, 5. $20 \mu \mathrm{M} \cdot \mathrm{OH}, 6.100 \mu \mathrm{M} \mathrm{O}_{2}^{-}$, 7. $100 \mu \mathrm{M} \mathrm{t}-\mathrm{BuOOH}, 8.1 \mathrm{mM} \mathrm{GSH}, 9.100 \mu \mathrm{M}$ Cys, 10. $100 \mu \mathrm{M}$ Hcy, 11. $100 \mu \mathrm{M} \mathrm{H}_{2} \mathrm{~S}, 12.100 \mu \mathrm{M} \mathrm{H}_{2} \mathrm{~S}_{2}, 13.100 \mu \mathrm{M} \mathrm{SO}_{3}{ }^{2-}, 14.100 \mu \mathrm{M}$ $\mathrm{HSO}^{3-}, 15.100 \mu \mathrm{M} \mathrm{SO}_{4}{ }^{2-}$.) $\lambda_{\mathrm{ex}}=450 \mathrm{~nm}$. 


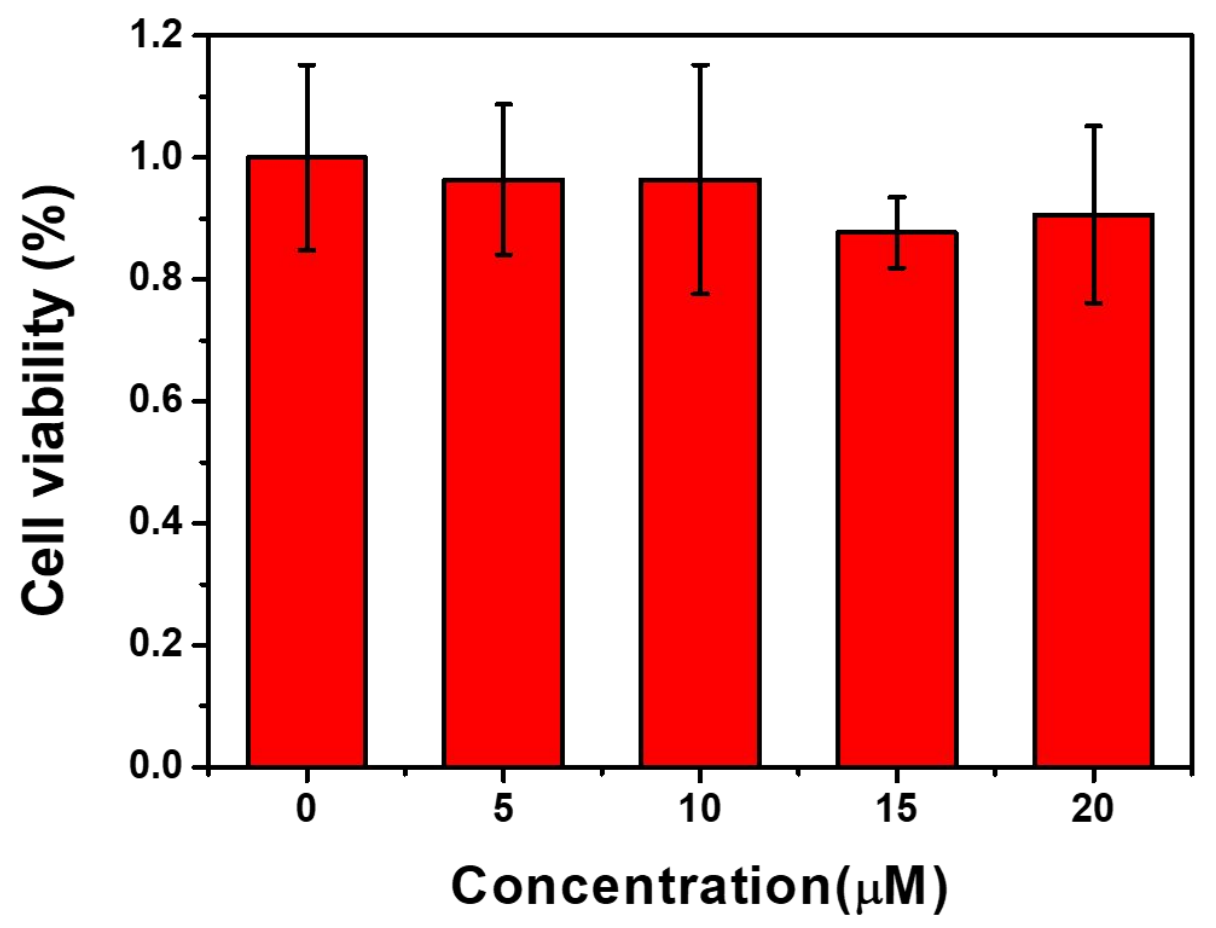

Figure. S11 The viability of HeLa cells at different concentrations of HQPQ-B after incubation for $12 \mathrm{~h}$ under dark.

\section{Additional cell experiment}

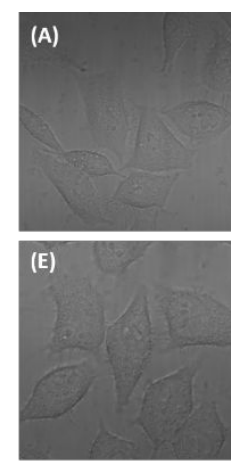

Bright field
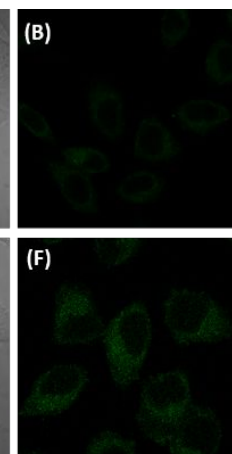

Green channel
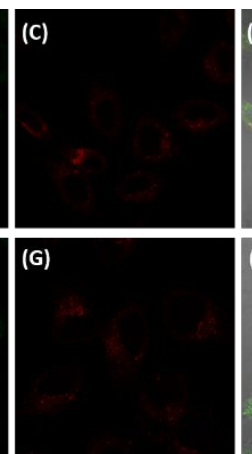

Red channel
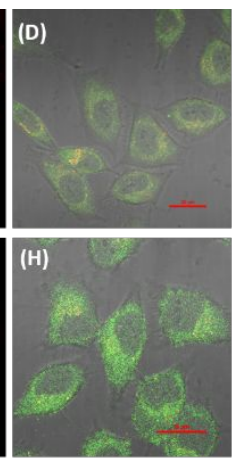

Overlap

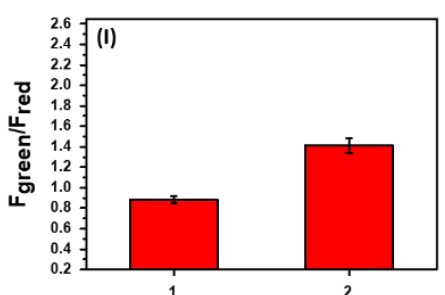

Figure. S12 Images of HeLa cells. (A-D) Cells incubated with HQPQ-B (10 $\mu \mathrm{M})$ for 40 min. (E-H) Cells incubated with HQPQ-B $(10 \mu \mathrm{M})$ and PMA $(1 \mu \mathrm{g} / \mathrm{mL})$ for 40 min. First column: bright field. Second column: $\lambda_{\mathrm{ex}}=405 \mathrm{~nm}$, Green channel: 500-550 $\mathrm{nm}$. Third column: $\lambda_{\mathrm{ex}}=405 \mathrm{~nm}$, Red channel: $663-738 \mathrm{~nm}$. Fourth column: Overlap of the green and red channels. Scale bars: $20 \mu \mathrm{m}$. (I) The ratiometric intensity of green/red fluorescence as a function of HQPQ-B (1) and HQPQ-B with PMA (2). 

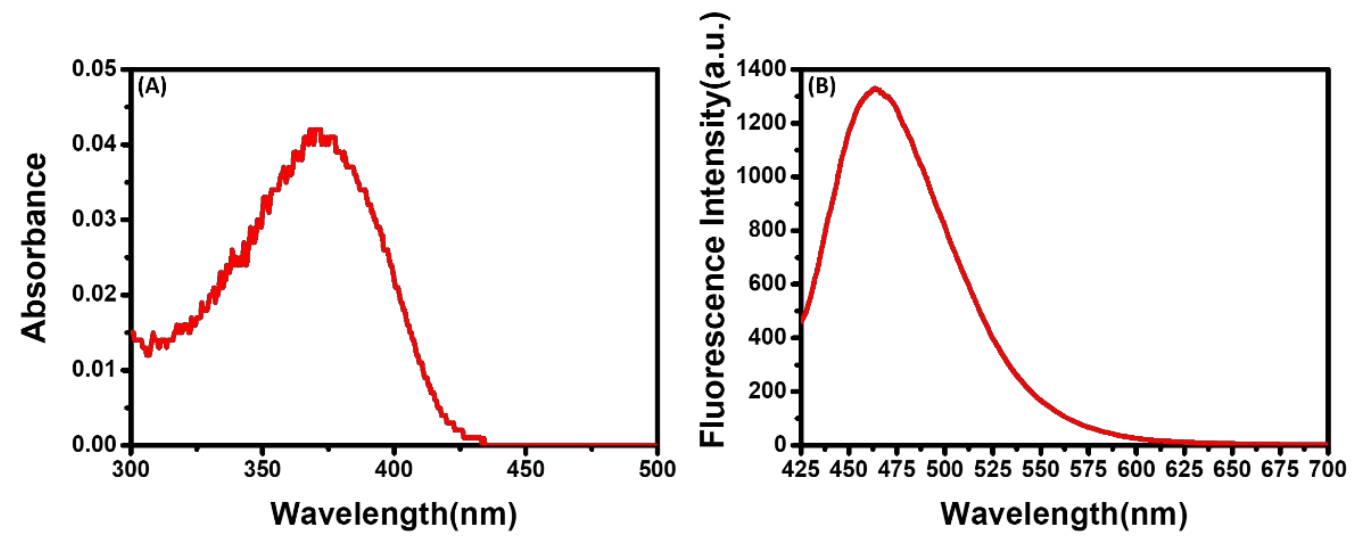

Figure. S13 (A) Absorbance response of Mito-Blue in $10 \mathrm{mM}$ DPBS pH= 7.4. (B) Fluorescence response of Mito-Blue in $10 \mathrm{mM} \mathrm{DPBS} \mathrm{pH}=7.4, \lambda_{\mathrm{ex}}=405 \mathrm{~nm}$.

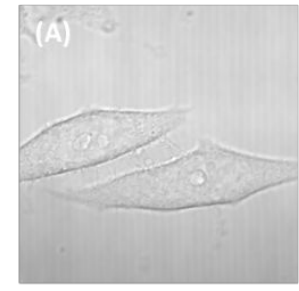

Bright field

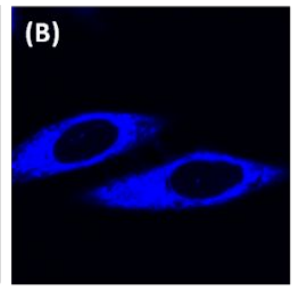

Blue channel

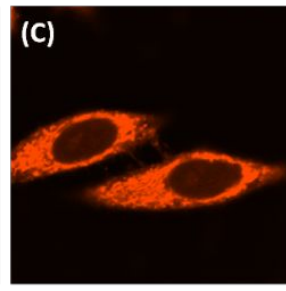

Red channel

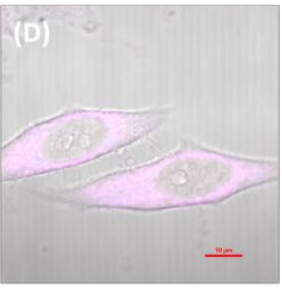

Overlap

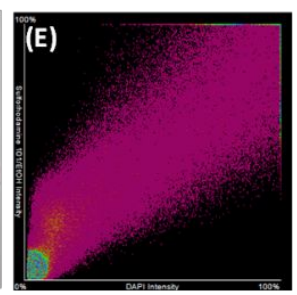

Scatter plot

Figure. S14 Confocal fluorescence images of HeLa cells co-stained with Mito-Blue and Mito-Red. (A-D) Cells pre-treated with Mito-Blue $(1 \mu \mathrm{M})$ and Mito-Red (100 $\mathrm{nM}$ ) for $30 \mathrm{~min}$ at $37{ }^{\circ} \mathrm{C}$. (A) Bright field. (B) $\lambda_{\mathrm{ex}}=405 \mathrm{~nm}$, Blue channel: 425-475 nm. (C) $\lambda_{\text {ex }}=561 \mathrm{~nm}$, Red channel: $570-620 \mathrm{~nm}$. (D) Overlap of the blue and red channels. (E) Scatter plot: the overlap of blue and green channels images. Pearson's correlation $=0.961034$. Scale bars: $10 \mu \mathrm{m}$.

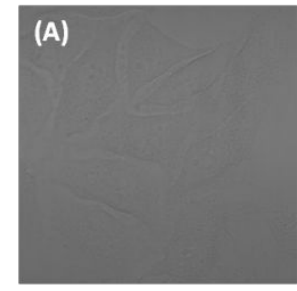

Bright field

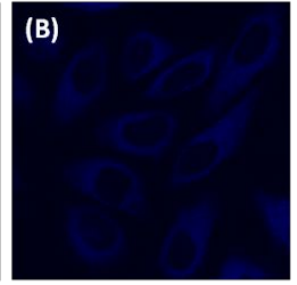

Blue channel

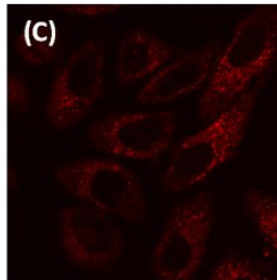

Red channel

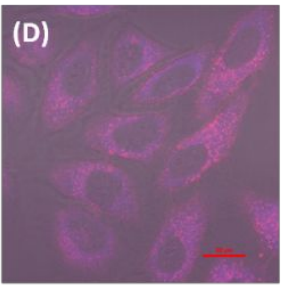

Overlap

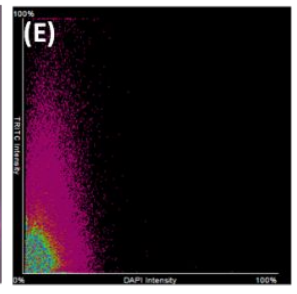

Scatter plot

Figure. S15 Confocal fluorescence images of HeLa cells co-stained with HQPQ-B and Lyso-Blue. (A-D) Cells pre-treated with HQPQ-B $(10 \mu \mathrm{M})$ and Lyso-Blue (100 $\mathrm{nM}$ ) for $30 \mathrm{~min}$ at $37{ }^{\circ} \mathrm{C}$. (A) Bright field. (B) $\lambda_{\mathrm{ex}}=405 \mathrm{~nm}$, Blue channel: 425-475 nm. (C) $\lambda_{\text {ex }}=405 \mathrm{~nm}$, Red channel: 663-738 nm. (D) Overlap of the blue and green channels. (E) Scatter plot: the overlap of blue and red channels images. Pearson's correlation $=0.394883$. Scale bars: $20 \mu \mathrm{m}$. 

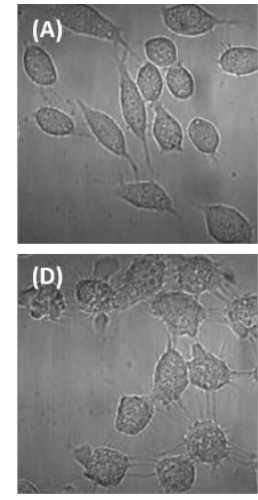

Bright field
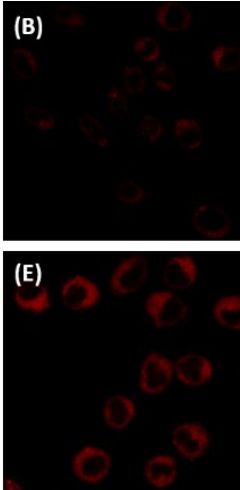

Red channel
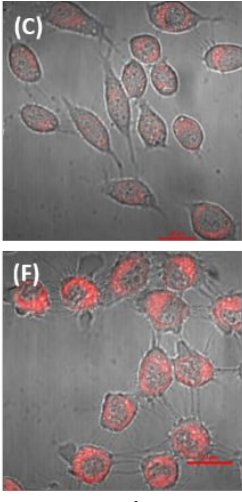

Overlap

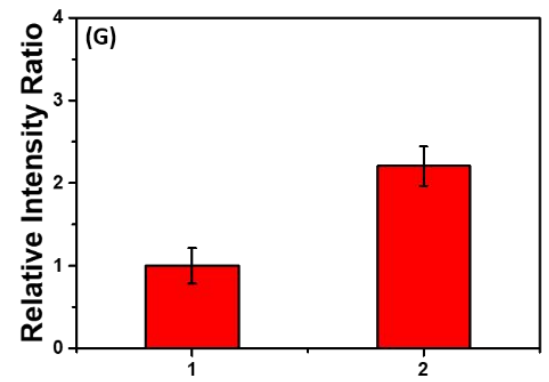

Figure. S16 Images of HeLa cells. (A-C) Cells incubated with HD-B $(10 \mu \mathrm{M})$ for 30 min. (D-F) Cells incubated with HD-B $(10 \mu \mathrm{M})$ for $30 \mathrm{~min}$, then $\mathrm{H}_{2} \mathrm{O}_{2}(200 \mu \mathrm{M})$ for 60 min. First column: bright field. Second column: $\lambda_{\mathrm{ex}}=640 \mathrm{~nm}$, Red channel: 663-738 nm. Third column: Overlap of the red channel and bright field. Scale bars: 20 $\mu \mathrm{m}$. (G) The fluorescence intensity as a function of HD-B (1) and HD-B with $\mathrm{H}_{2} \mathrm{O}_{2}(2)$. 


\section{MS Spectra and NMR spectra}

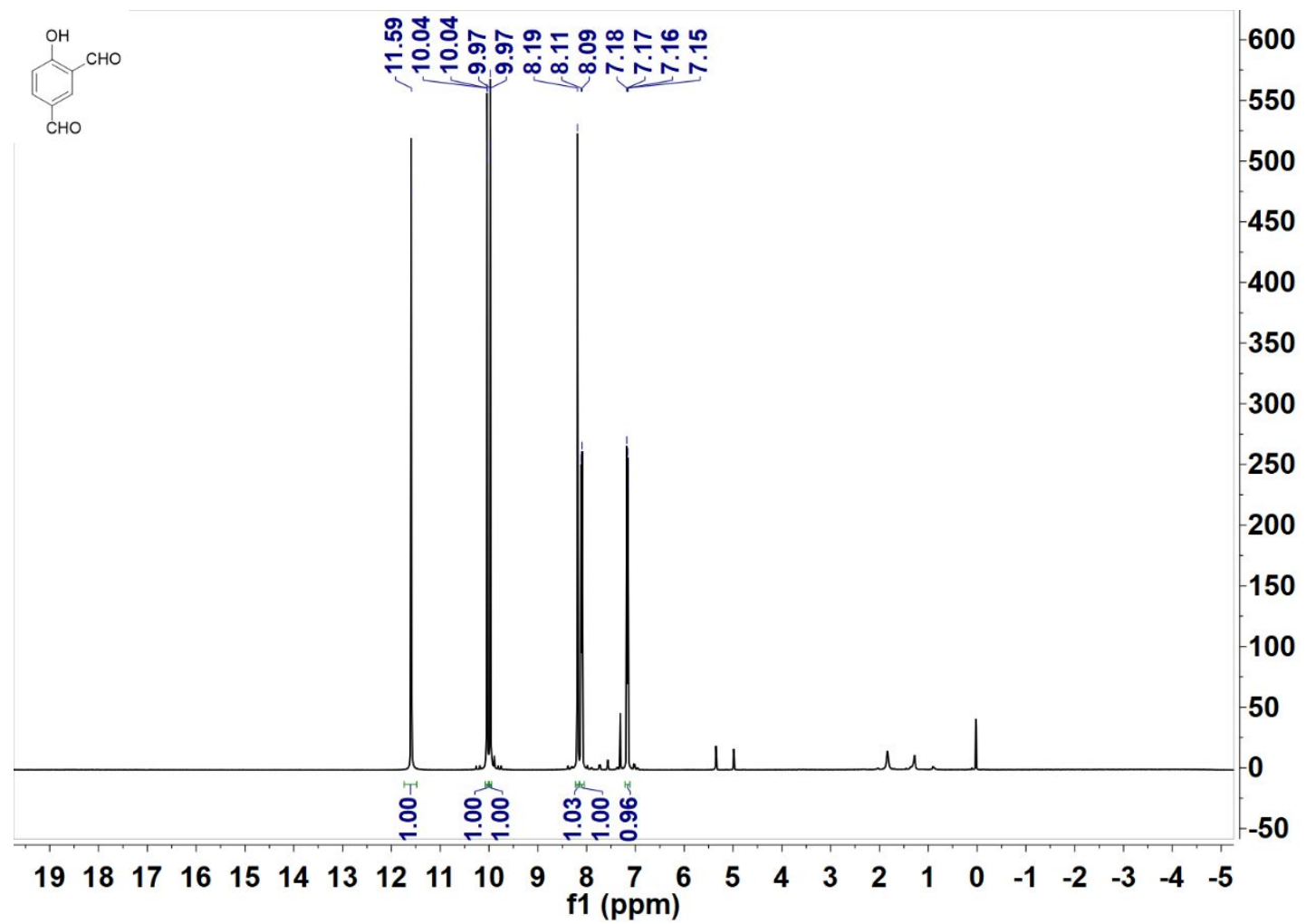

Figure. S17 Compound 2 - ${ }^{1} \mathrm{H}-\mathrm{NMR}$ spectrum.

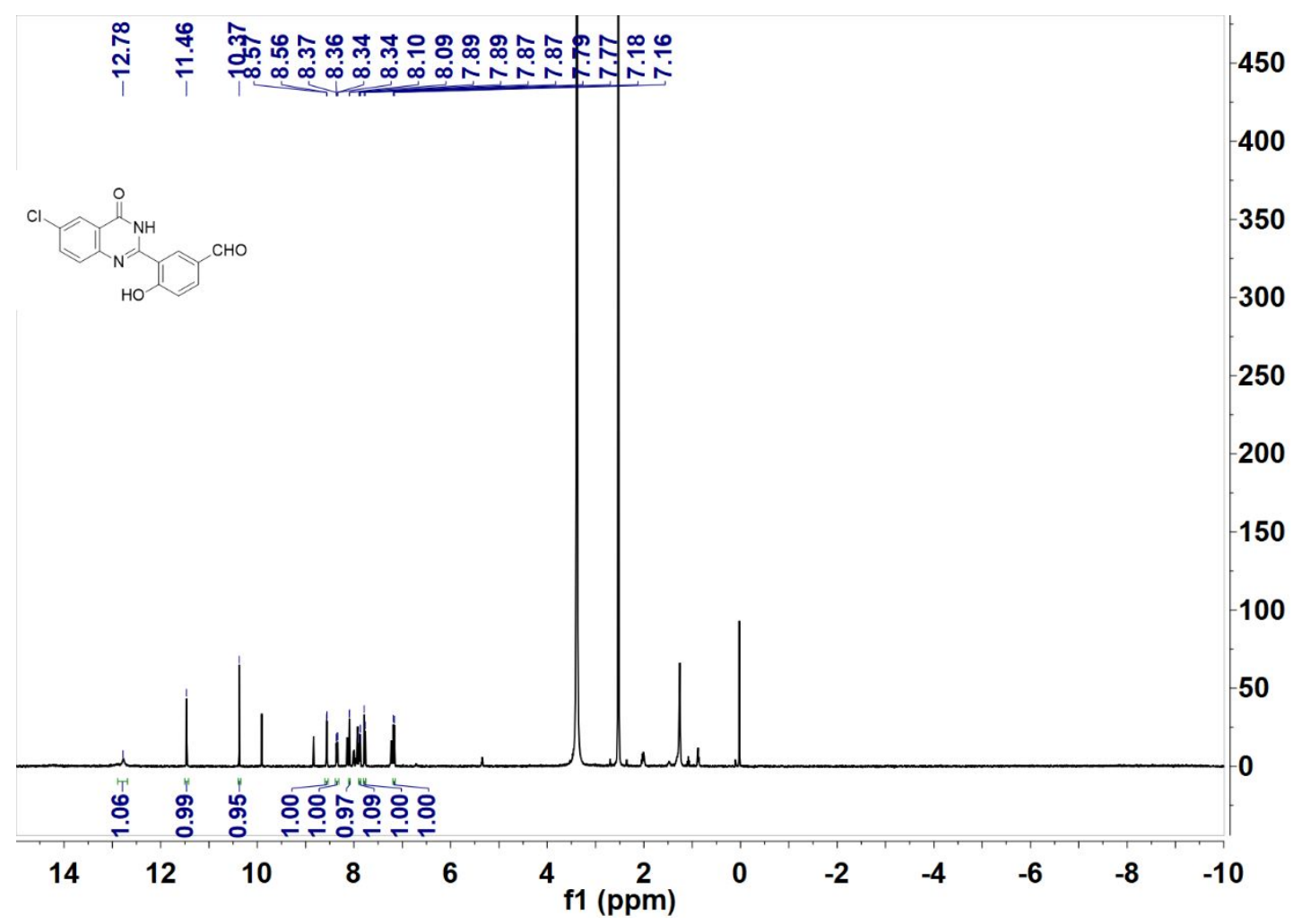

Figure. S18 Compound $3-{ }^{1} \mathrm{H}-\mathrm{NMR}$ spectrum. 


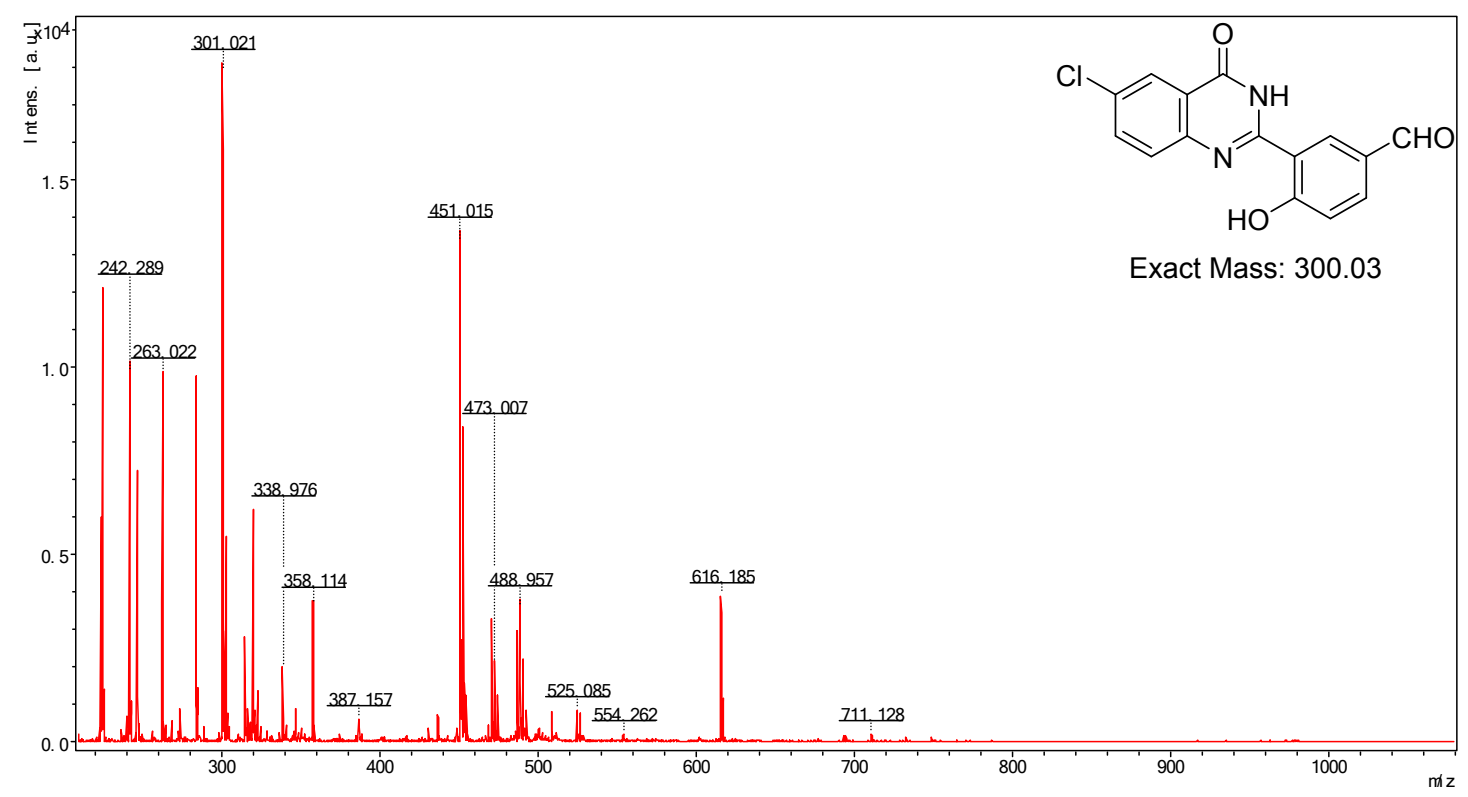

Figure. S19 Compound 3 - MALDI-TOF mass spectrum.

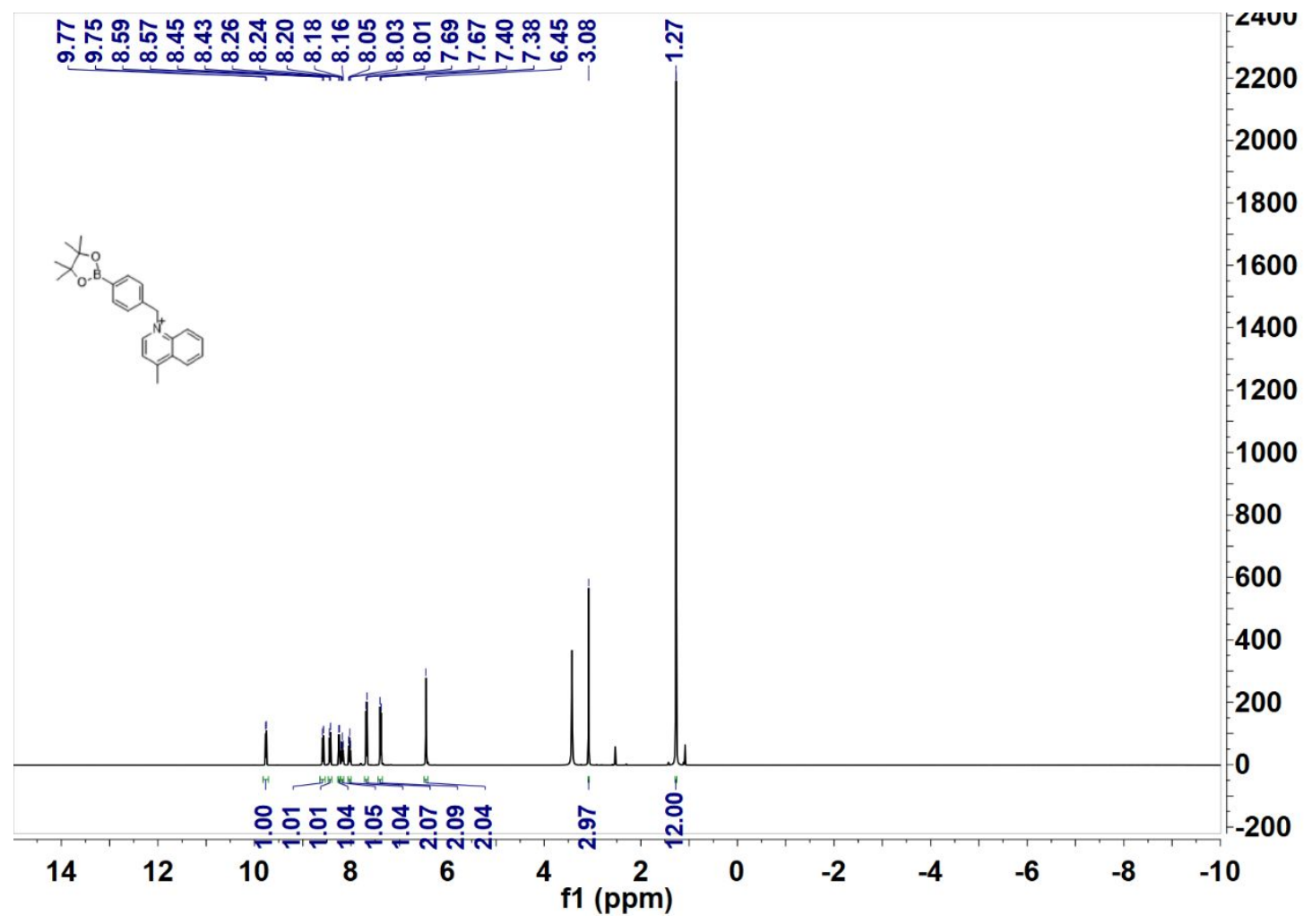

Figure. S20 Compound 5 - ${ }^{1} \mathrm{H}-\mathrm{NMR}$ spectrum. 


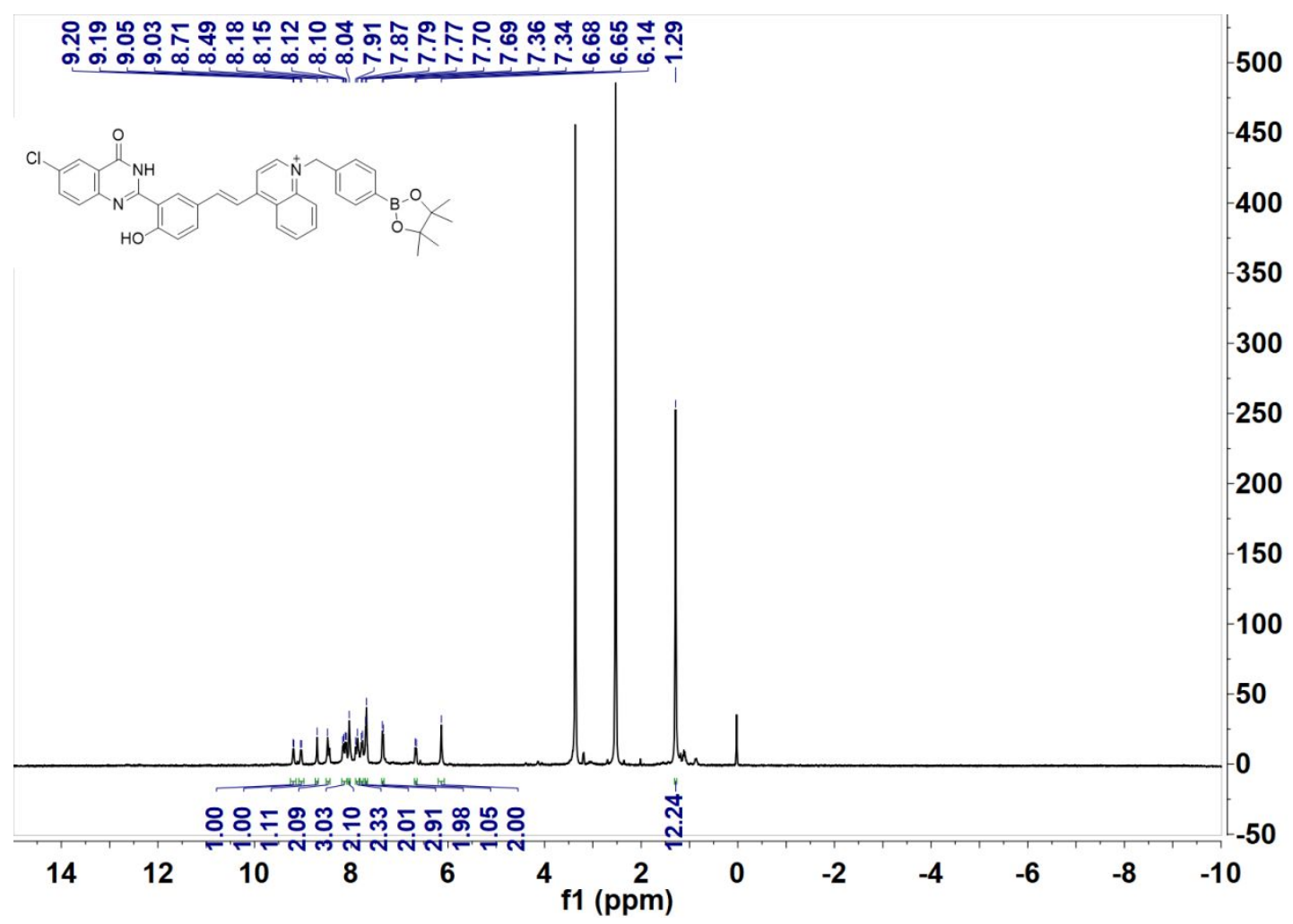

Figure. S21 HQPQ-B - ${ }^{1} \mathrm{H}-\mathrm{NMR}$ spectrum.

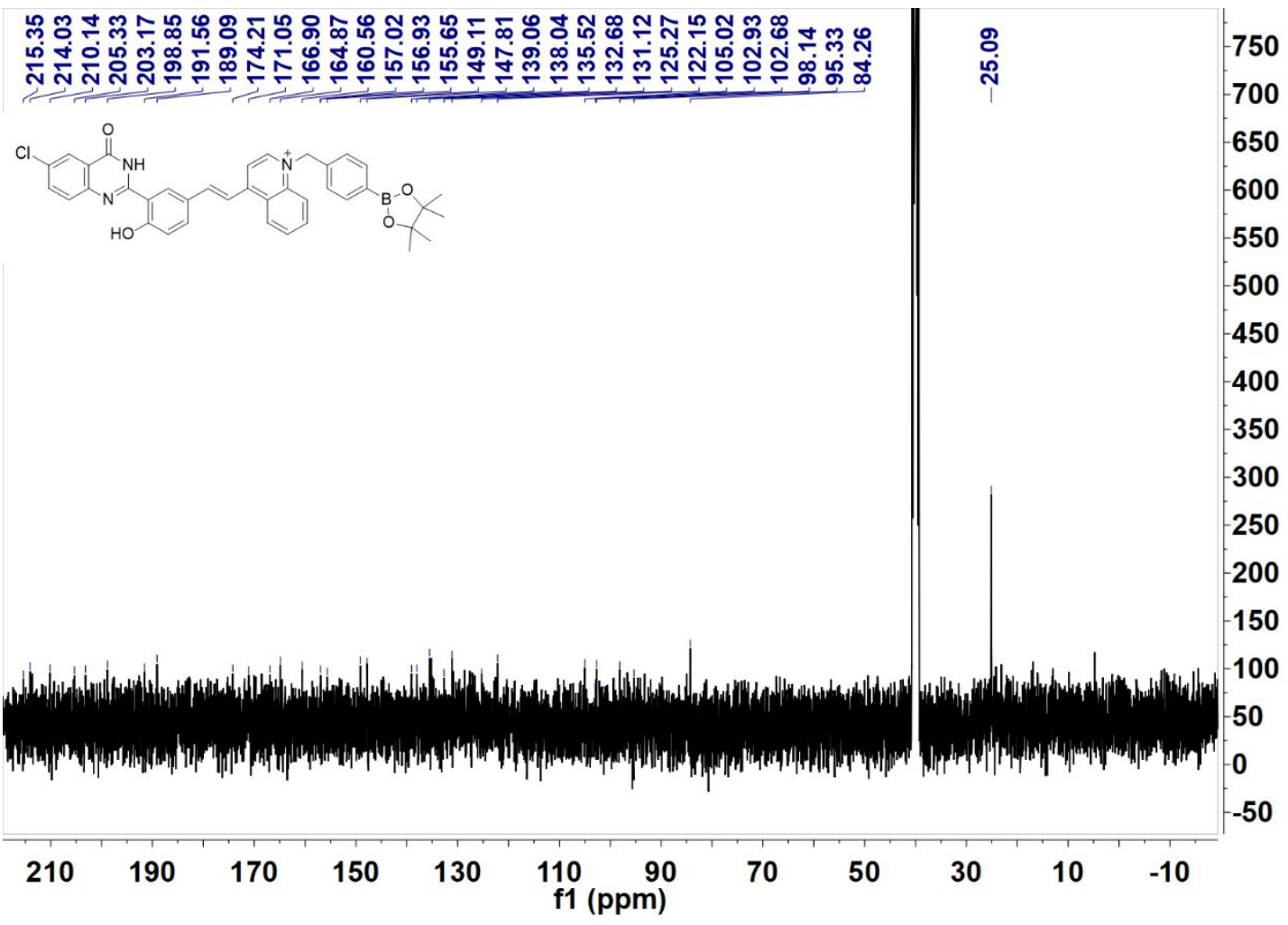

Figure. S22 HQPQ-B - ${ }^{13} \mathrm{C}-\mathrm{NMR}$ spectrum. 


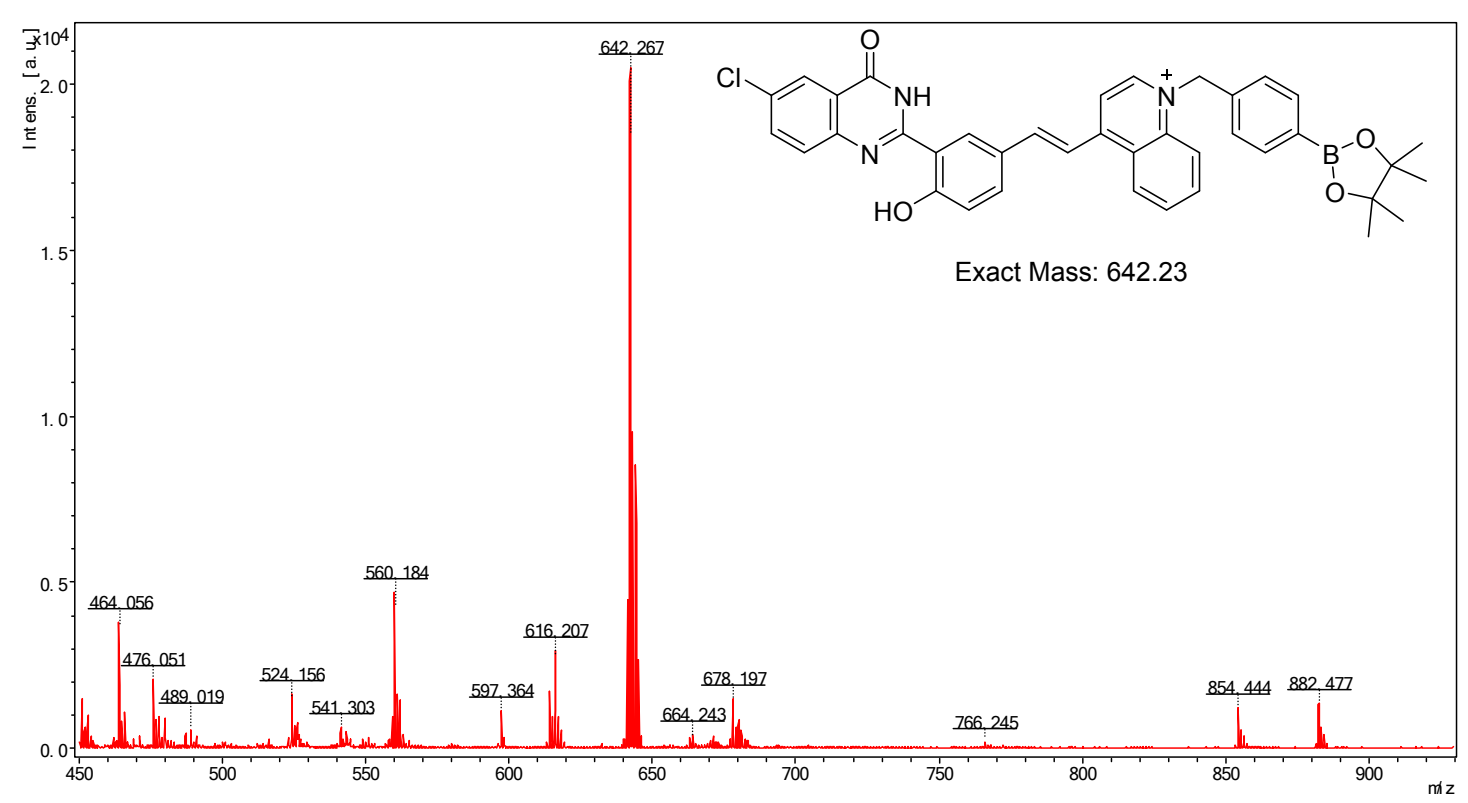

Figure. S23 HQPQ-B - MALDI-TOF mass spectrum.

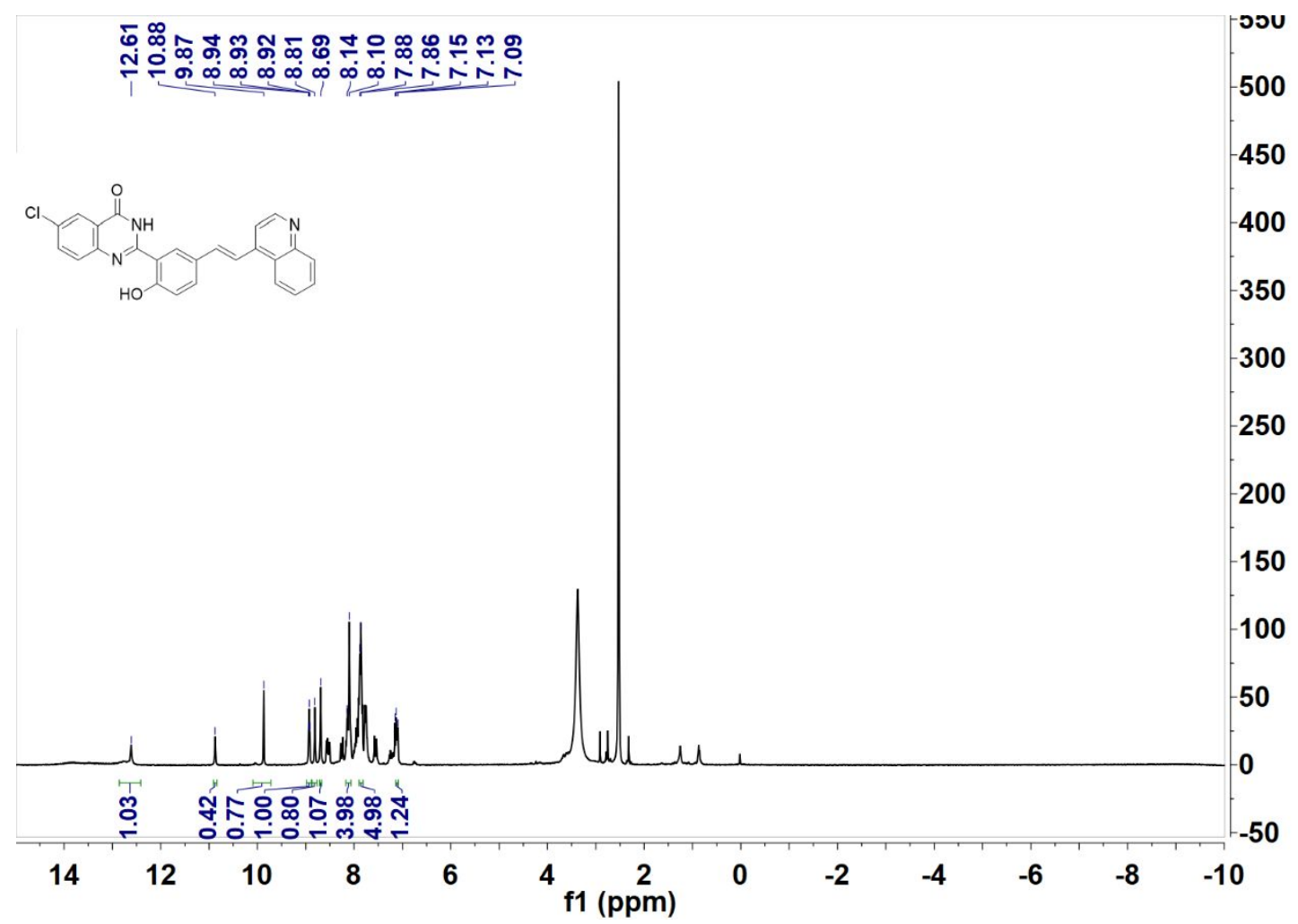

Figure. S24 HQPQ - ${ }^{1} \mathrm{H}-\mathrm{NMR}$ spectrum. 


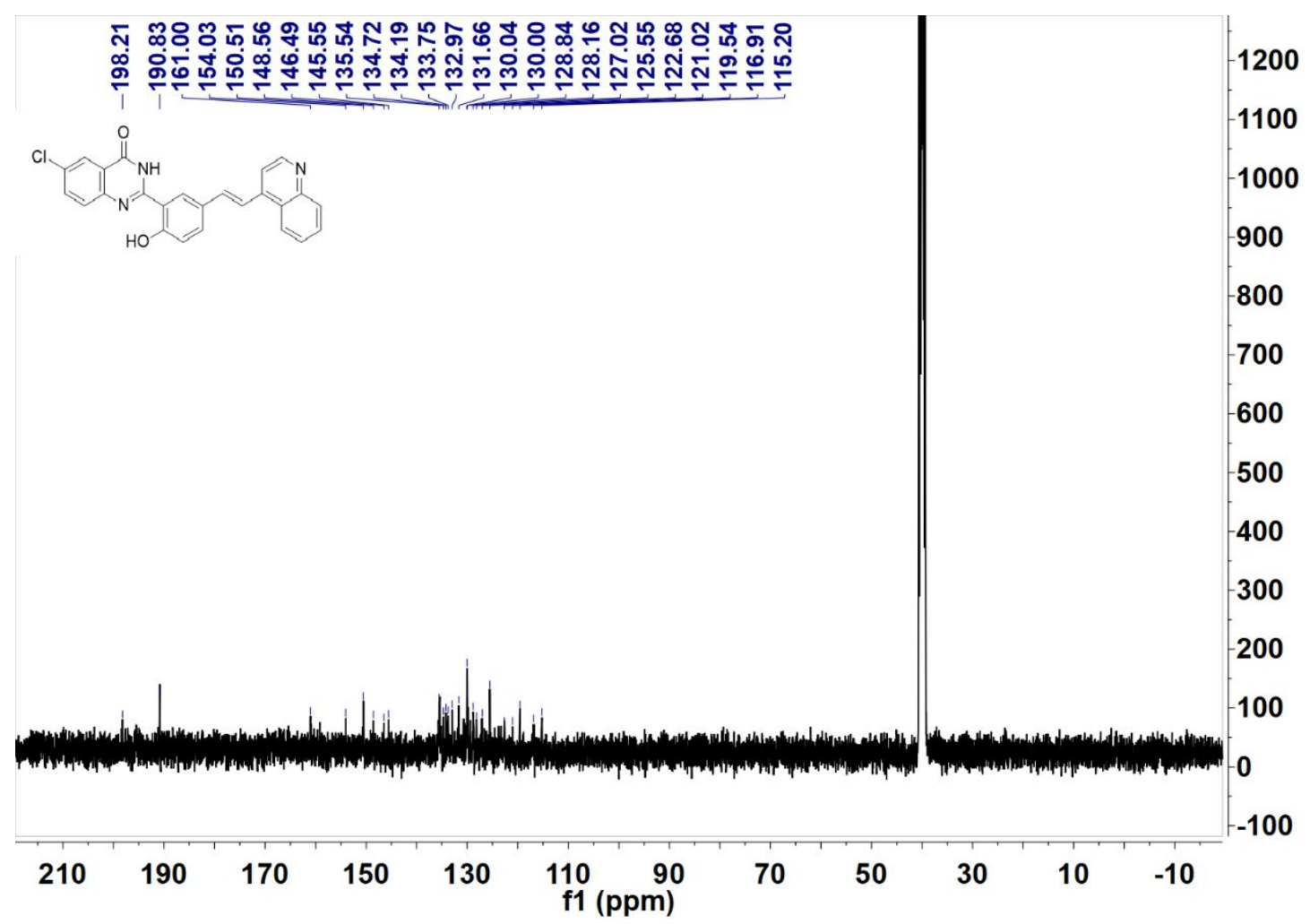

Figure. S25 HQPQ - ${ }^{13} \mathrm{C}-\mathrm{NMR}$ spectrum.

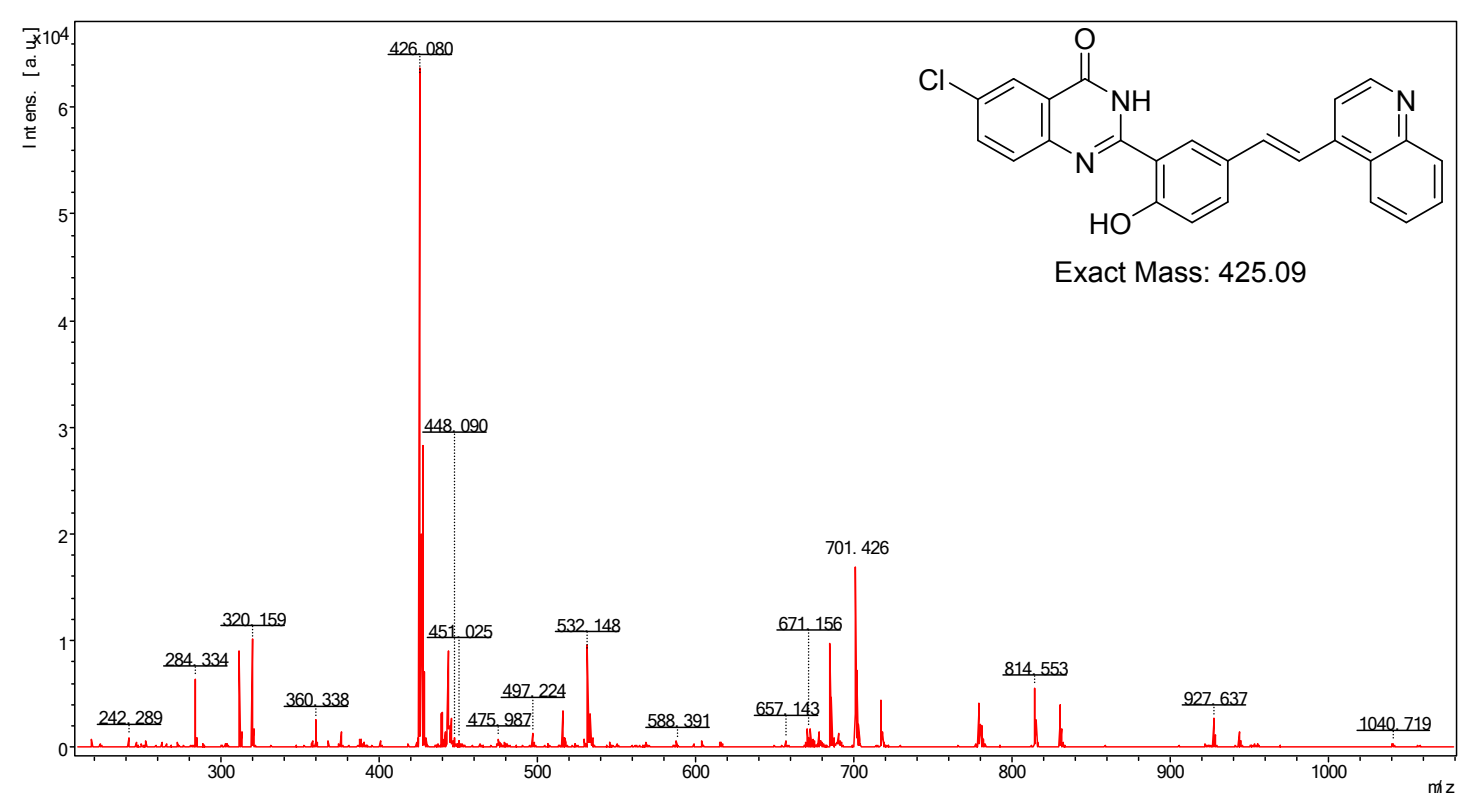

Figure. S26 HQPQ - MALDI-TOF mass spectrum. 


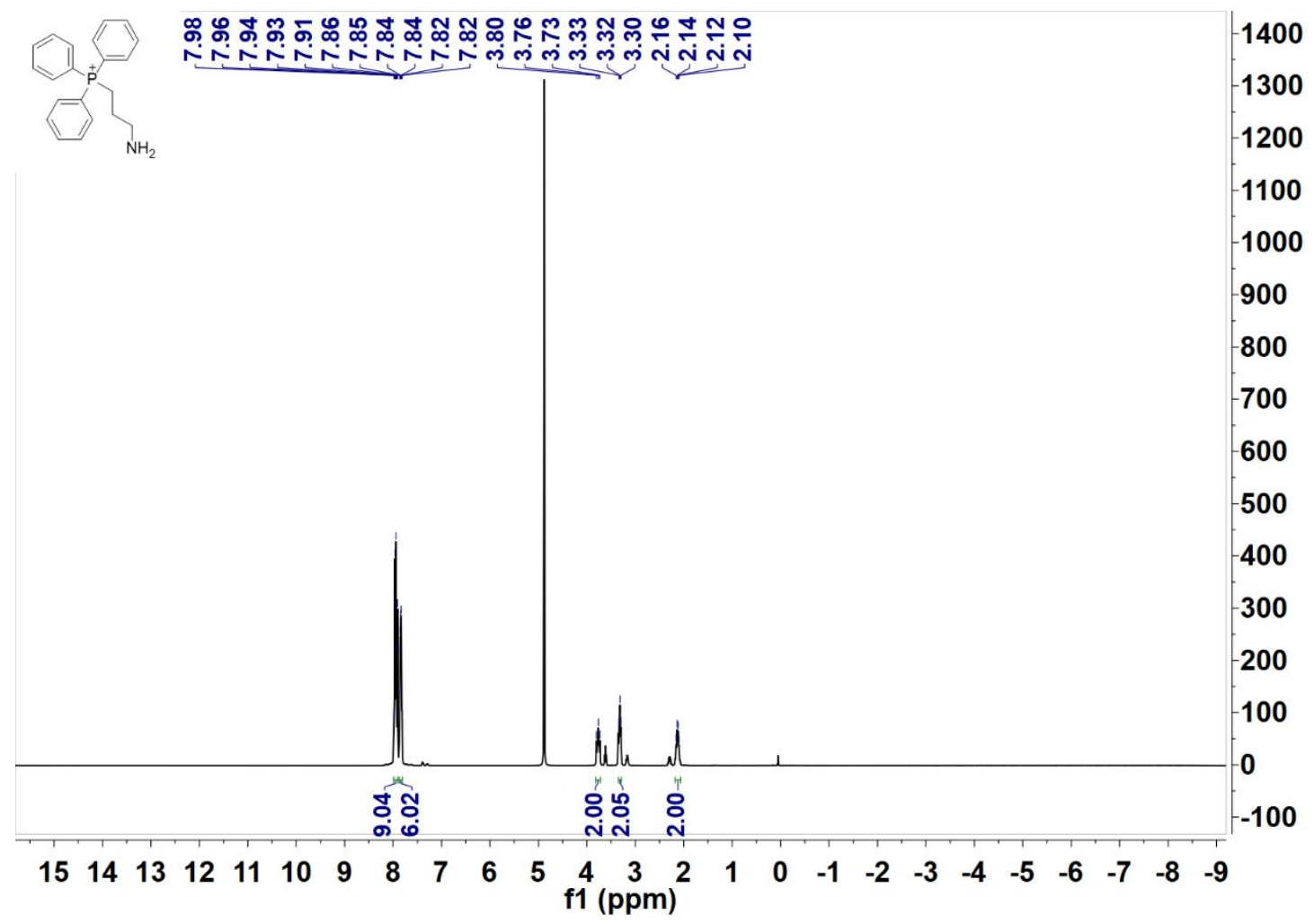

Figure. S27 Compound 7 - ${ }^{1} \mathrm{H}-\mathrm{NMR}$ spectrum.

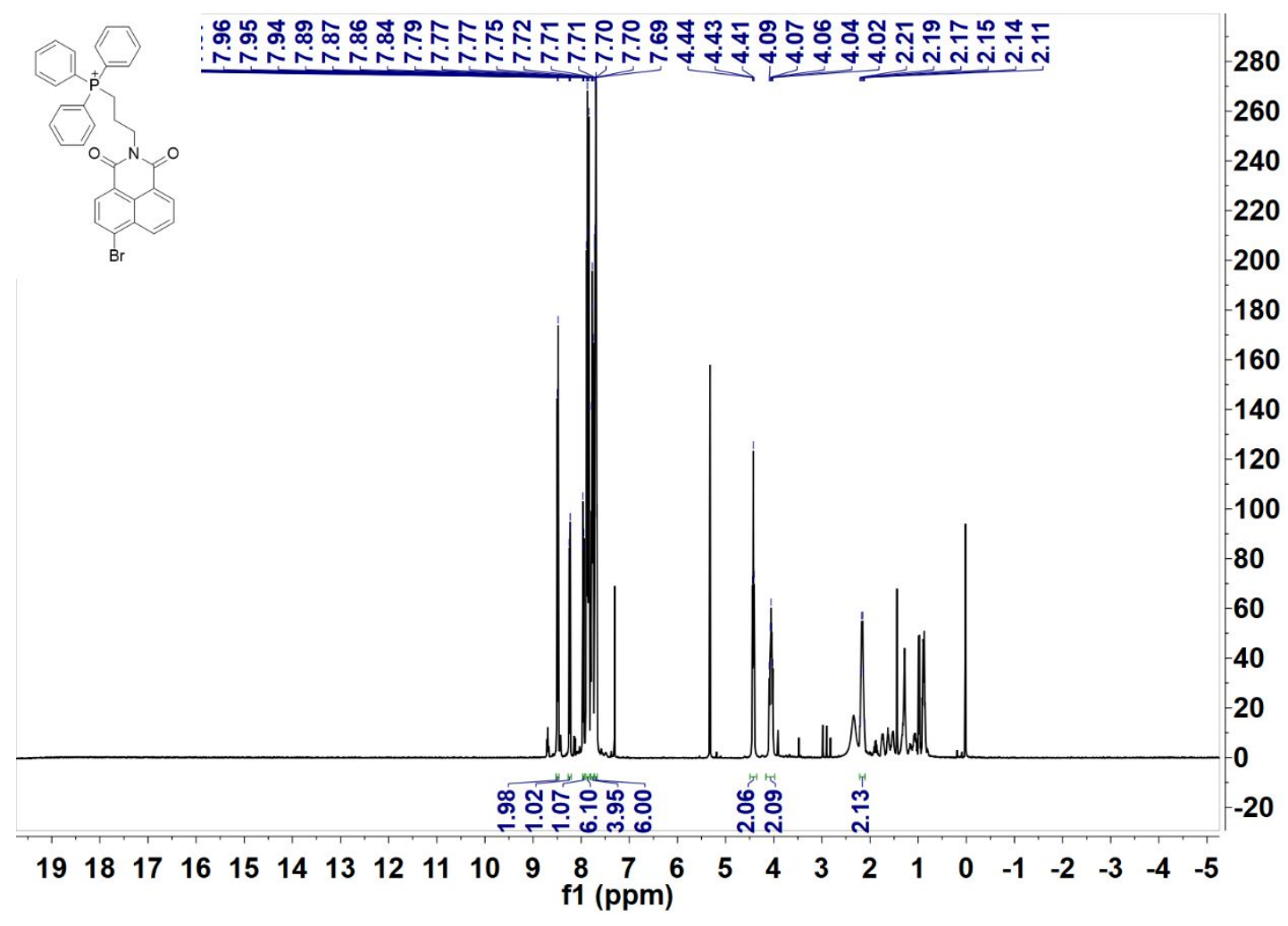

Figure. S28 Compound 8 - ${ }^{1} \mathrm{H}-\mathrm{NMR}$ spectrum. 


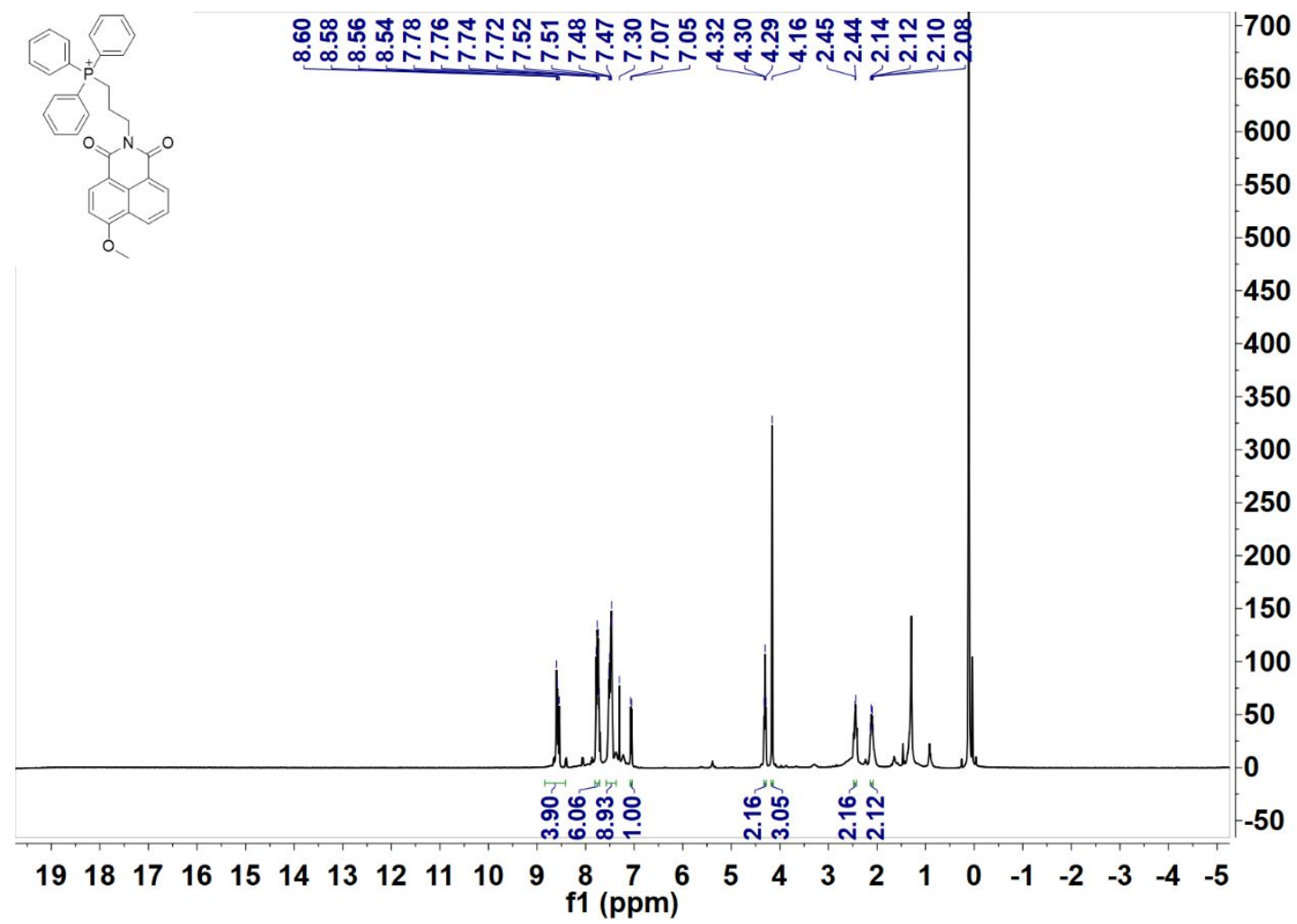

Figure. S29 Mito-Blue - ${ }^{1} \mathrm{H}-\mathrm{NMR}$ spectrum.

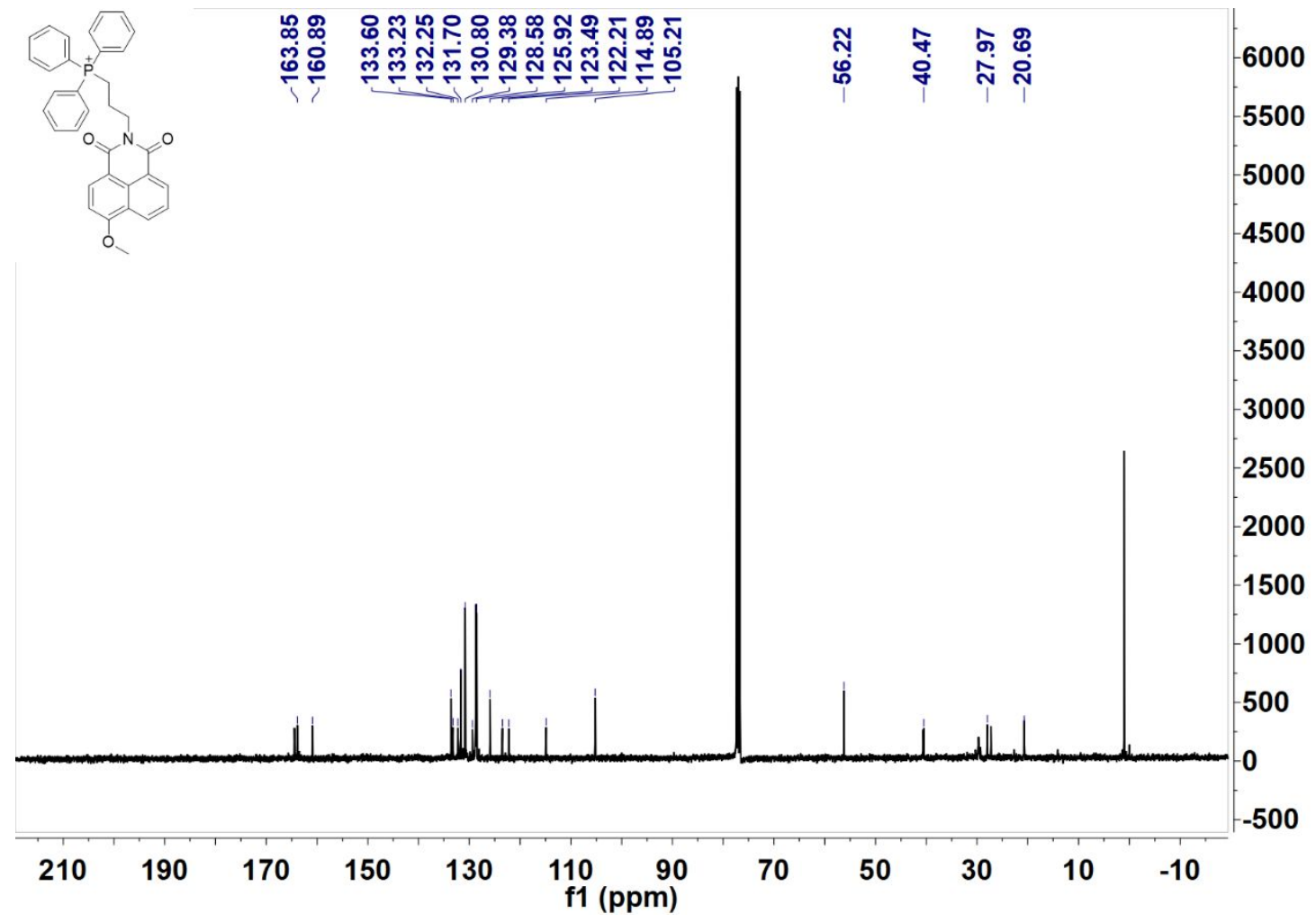

Figure. S30 Mito-Blue - ${ }^{13} \mathrm{C}-\mathrm{NMR}$ spectrum. 


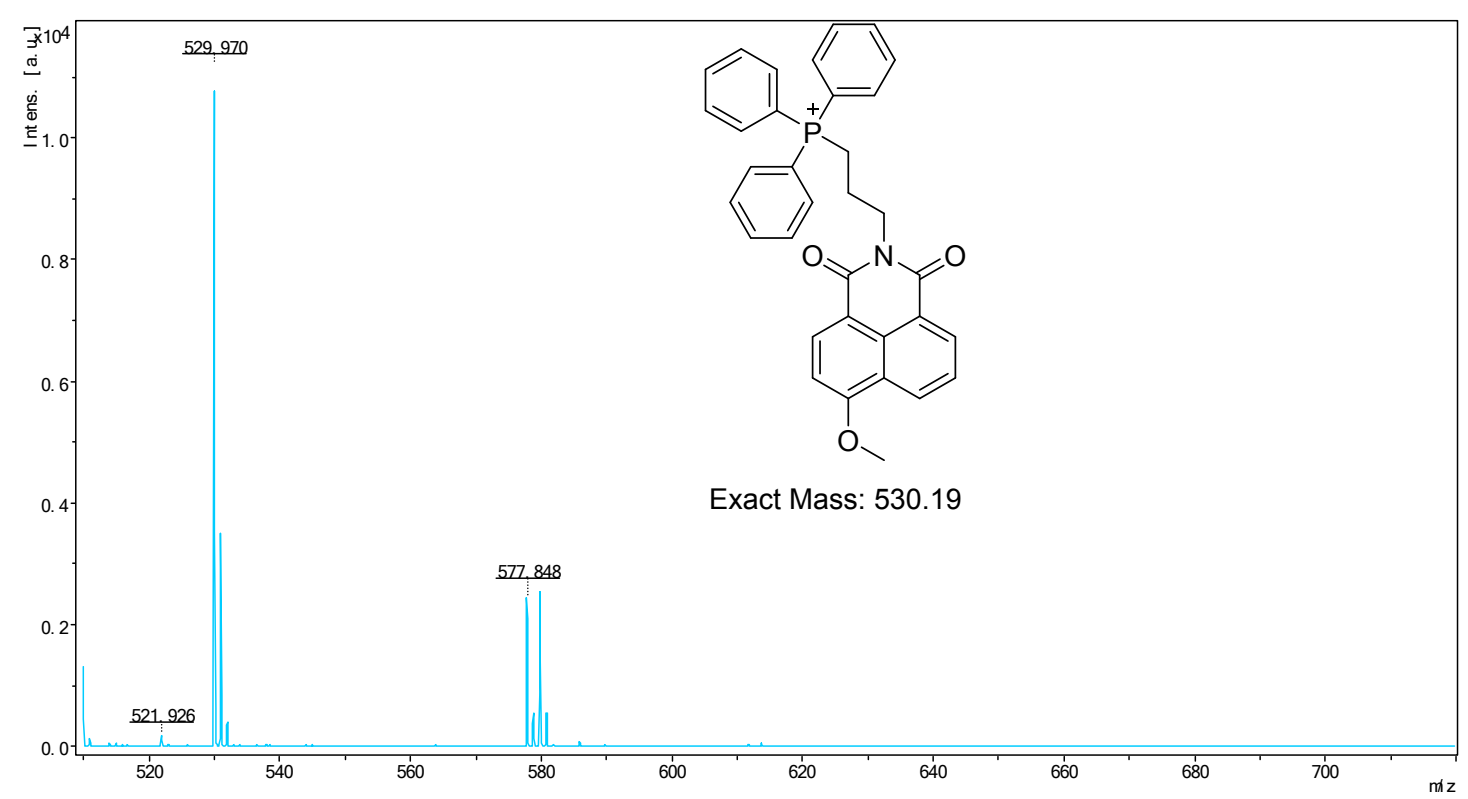

Figure. S31 Mito-Blue - MALDI-TOF spectrum.

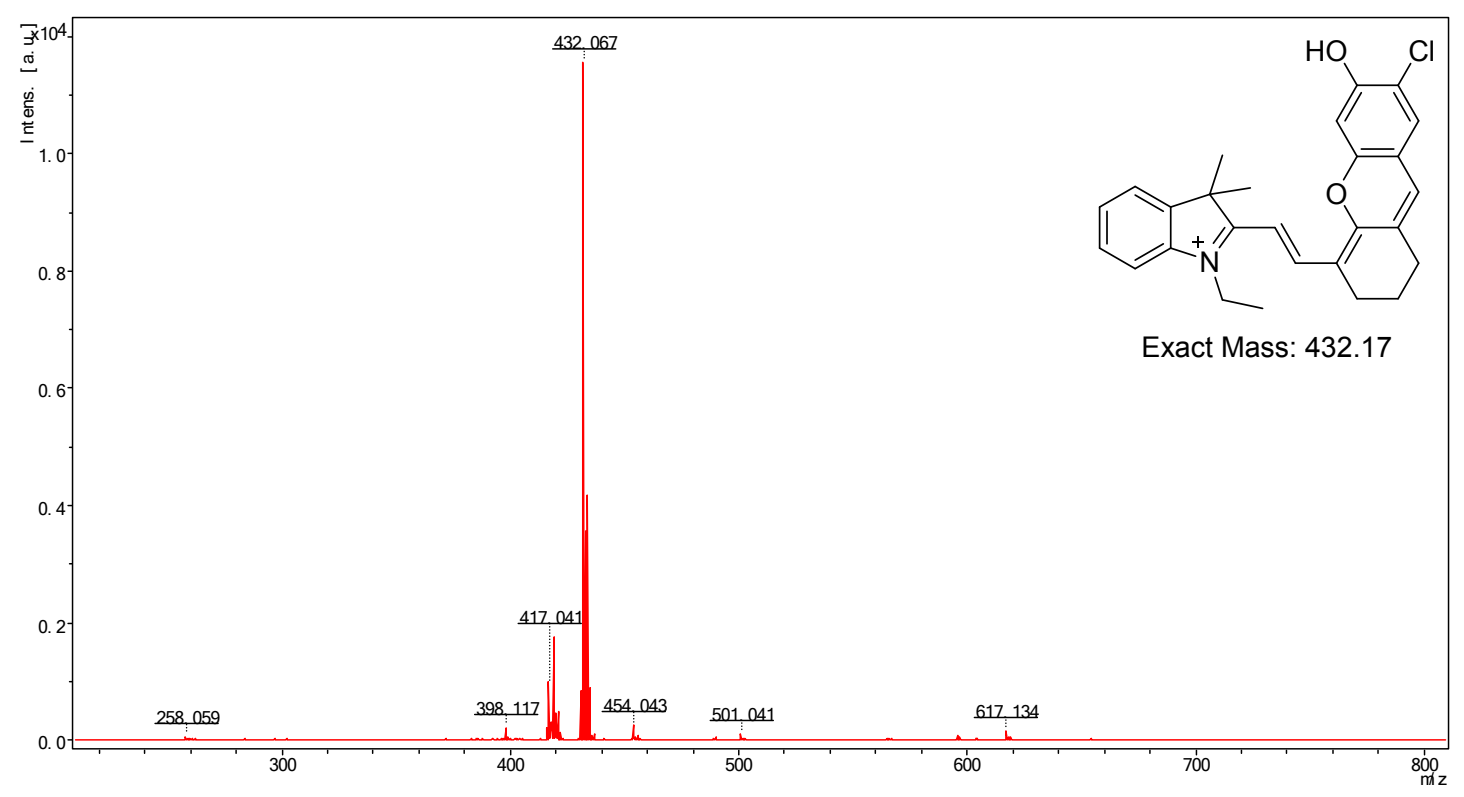

Figure. S32 HD - MALDI-TOF spectrum. 


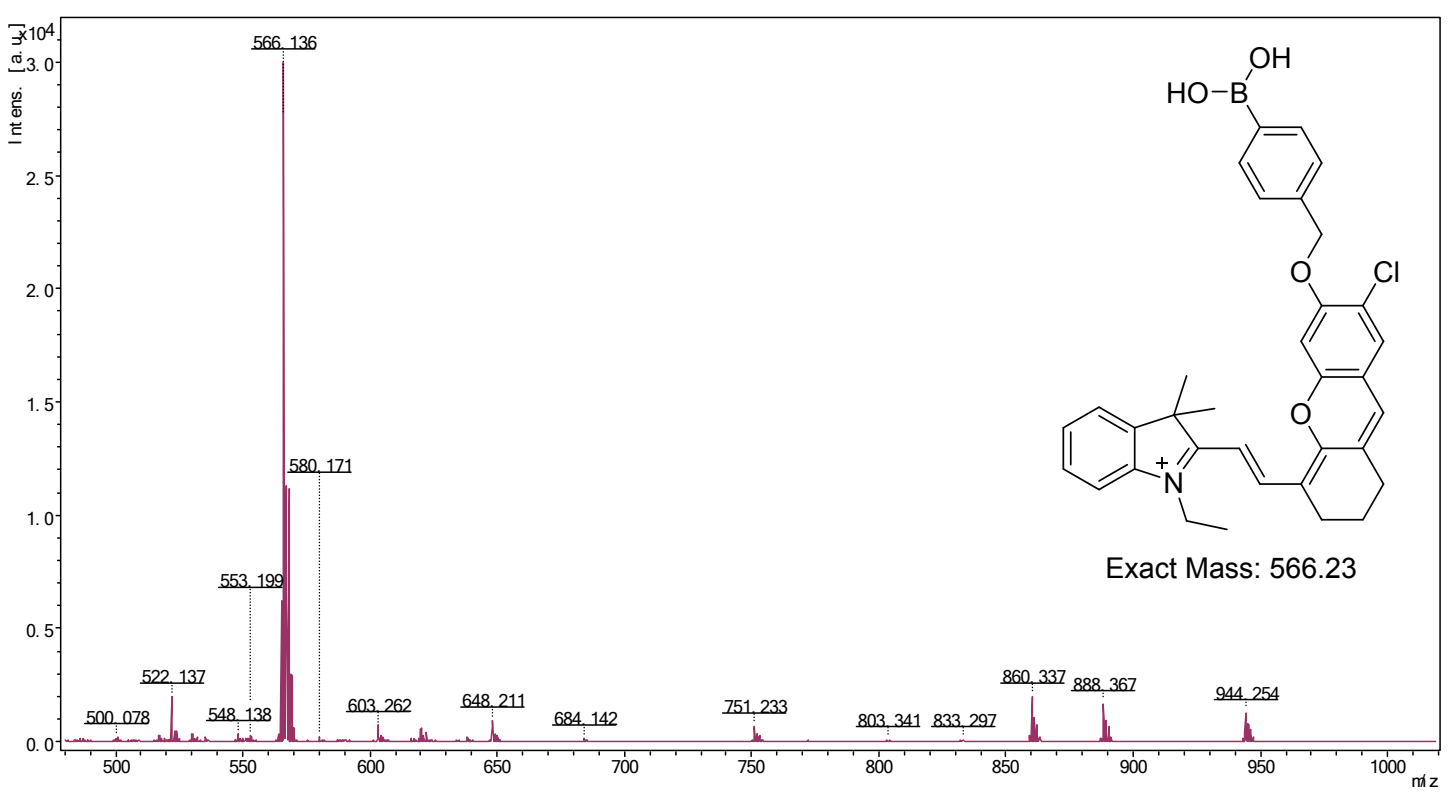

Figure. S33 HD-B - MALDI-TOF spectrum.

\section{References}

(1) Zhou, L.; Lu, D. Q.; Wang, Q.; Hu, S.; Wang, H.; Sun, H.; Zhang, X. A high-resolution mitochondria-targeting ratiometric fluorescent probe for detection of the endogenous hypochlorous acid. Spectrochim. Acta A. 2016, 166, 129-134

(2) Xu, J.; Zhang, Y.; Yu, H.; Gao, X.; Shao, S. Mitochondria-Targeted Fluorescent Probe for Imaging Hydrogen Peroxide in Living Cells. Anal. chem. 2016, 88, 1455-1461.

(3) Lv, Y.; Dan, C.; Dongdong, S.; Chen, M.; Yin, B. C.; Yuan, L.; Zhang, X. B. Visualization of oxidative injury in the mouse kidney using selective superoxide anion fluorescent probes. Chem. Sci. 2018, 9, 7606-7613.

(4) Yuan, L.; Lin, W.; Zhao, S.; Gao, W.; Chen, B.; He, L.; Zhu, S. A Unique Approach to Development of Near-Infrared Fluorescent Sensors for in Vivo Imaging. J. Am. Chem. Soc. 2012, 134, $13510-13523$ 